$12-2013$

\title{
Titanic: Consuming the Myths and Meanings of an Ambiguous Brand
}

Stephen Brown

Pierre McDonagh

Clifford J. Shultz

Loyola University Chicago, cshultz@luc.edu

Follow this and additional works at: https://ecommons.luc.edu/business_facpubs

Part of the Other Business Commons

\section{Recommended Citation}

Brown, S, McDonagh, P, and Shultz CJ. "Titanic: consuming the myths and meanings of an ambiguous brand" in Journal of Consumer Research 40(4), 2013.

This Article is brought to you for free and open access by the Faculty Publications and Other Works by Department at Loyola eCommons. It has been accepted for inclusion in School of Business: Faculty Publications and Other Works by an authorized administrator of Loyola eCommons. For more information, please contact ecommons@luc.edu.

\section{(c) (1) (9)}

This work is licensed under a Creative Commons Attribution-Noncommercial-No Derivative Works 3.0 License. (c) 2013 by Journal of Consumer Research, Inc. 


\title{
Titanic: Consuming the Myths and Meanings of an Ambiguous Brand
}

\author{
STEPHEN BROWN \\ PIERRE MCDONAGH \\ CLIFFORD J. SHULTZ ॥
}

\begin{abstract}
Myths have come of age in consumer research. In the 22 years since Levy's inaugural article, the literature has grown at an impressive rate. Yet important questions remain unanswered: What makes some myths especially meaningful to consumers? Why are certain consumer myths more prevalent and less perishable than others? This article argues that ambiguity is an influential factor. Using the RMS Titanic as an empirical exemplar, it unpacks the principal forms of myth-informed ambiguity surrounding "the unsinkable brand." Predicated on William Empson's hitherto unsung principles of literary criticism, the article posits that ambiguity in its multifaceted forms is integral to outstanding branding and consumer meaning making, as well as myth appeal more generally.
\end{abstract}

\begin{abstract}
Like poetry and music, mythology should awaken us to rapture, even in the face of death and the despair we may feel at the prospect of annihilation. (Armstrong 2005, 8)
\end{abstract}

\begin{abstract}
A pril, according to T. S. Eliot (1922), is the cruelest month. If 2012 is anything to go by, it is also the craziest. April 2012 was the month when the world went wild for Titanic, the "unsinkable" steamship that sank on its maiden voyage 100 years earlier (Sides 2012). The centennial of the sinking was commemorated in many cities associated with the legendary White Star liner, including Liverpool, Southampton, Cherbourg, Cobh, and New York (Ward 2012). It was likewise marked by manifold works of popular culture: movies, musicals, murals, magazine articles, museum exhibitions, computer games, iPhone apps, requiem masses, and more (Economist 2012). Memorabilia sellers were also out in force, happily slapping images of the ill-fated liner on everything from baseball caps to candy bars (McKeown 2012).
\end{abstract}

Stephen Brown (sfx.brown@ulster.ac.uk) is professor of marketing research, University of Ulster, Newtownabbey, County Antrim, BT37 0QB, UK. Pierre McDonagh (pierre.mcdonagh@dcu.ie) is senior lecturer in marketing, Dublin City University, Dublin 9, Ireland. Clifford J. Shultz II (cjs2@luc.edu) is professor and Charles H. Kellstadt Chair of Marketing, Loyola University Chicago, Chicago, IL 60611. The authors acknowledge the enormously helpful input of the editor, associate editor, and reviewers.

Laura Peracchio served as editor and Craig Thompson served as associate editor for this article.

Electronically published June 21, 2013
Viewed dispassionately, this fixation is hard to fathom. The loss of life on Titanic was minuscule compared to prior disasters and, when set against subsequent catastrophes, the 1912 tragedy barely registers (Eyers 2013). Yet Titanic is still seen as a quintessential calamity, the model against which human misfortunes are measured (Biel 2012). In the annals of mishap, the ship stands shoulder to shoulder with the assassinations of Lincoln and Kennedy (Wade 1986), the Challenger space shuttle explosion (Howells 2012), and Titanic's terrible twenty-first-century equivalent, September 11, 2001 (Pellegrino 2012). For Molony (2012), RMS Titanic is nothing less than the Rolls-Royce of misadventure, an iconic superbrand of the mortality market.

Branding Titanic in this way may seem distasteful, bordering on obscene, but it is in keeping with the recent turn to "dark tourism" (Lennon and Foley 2000), that is, the commodification of locations and occasions associated with death and destruction (Stone and Sharpley 2008). The selling of the Titanic, however, is not just another instance of humankind's appetite for the macabre (Goulding, Saren, and Lindridge 2013). It is a prime example of myth making. As many commentators have noted, it is the myth of the unsinkable ship - myths, rather-that has made this ambiguous brand meaningful to millions of consumers (Barczewski 2004; Biel 2012; Cameron 2011; Foster 1997).

This article examines the Titanic brand through a mythological lens, with a view to unpacking its ambiguities. After summarizing the mythic traditions in consumer research, considering the contested meanings of ambiguity, and recounting the oft-told tale of the Titanic, we explain our methodological approach, which is predicated on the prin- 
ciples of consumer culture theory (CCT) in general and Empson's ambiguity-led literary criticism in particular. The results reveal a spectrum of Titanic ambiguities, from confusion through contradiction to cumulation, ambiguities that help account for the mythical brand's consumer appeal, not least in Northern Ireland, where the meanings of the vessel have metamorphosed from shameful mortification to shameless monetization, while crossing a seemingly sacrosanct religious divide.

In terms of its contributions, our article responds to Arnould and Thompson's $(2005,876)$ call for historically informed analyses of "the commodity form (broadly defined)." Empirically, it extends CCT's repertoire to all four composers of brand stories-owners, consumers, influencers, and popular culture (Holt 2003) - thereby adding additional instruments to the myth-ensemble. Methodologically, it returns to the corpus of literary criticism largely neglected since the passing of its prime mover, Barbara B. Stern. Conceptually, it demonstrates that ambiguity is a multifaceted construct, not so much a property as a panorama with specific points of interest. Paradigmatically, our article adheres to the principles of the liberal arts, insofar as it extracts enlightenment from a single, stupendous case study rather than a representative sample of Titanic fanatics. And, rhetorically, it considers the implications of ambiguous branding for consumer research, going forward.

\section{MYTH MATTER}

In his compact introduction to the principal theories of myth, Segal (2004) identifies 10 academic domains where the subject looms large. These range from religious studies and psychology to anthropology and literary criticism. If Segal were writing his text today, he might be tempted to add consumer research to his list of traditions. As a glance through past issues of JCR (and the ACR proceedings) attests, our field is replete with writing and theorizing about myth (Thompson 2004).

When this compendious body of work is examined, it is evident that considerable progress has been made on Levy's $(1981,51)$ inaugural question, "What is myth really about?" Rather less clear, though, is "why particular myths resonate" (Holt 2004, 236). How come some myths are more powerful or persuasive than others? Why is it that certain mythsand the iconic brands that embody them-are eagerly embraced by consumers and integrated into their lives, whereas others fail to strike a chord or ring true?

According to Stern (1995), archetypes are the answer. Following Northrop Frye, the founding father of archetypal literary criticism, she argues that four fundamental mythoi - tragedy, comedy, irony, and romance-underpin consumers' many and varied attempts to make sense of the world and are made manifest on ritualistic occasions such as Thanksgiving. Deep structures in consumer myth-making are likewise discerned by Belk and Tumbat (2003), Hirschman (1988), Holbrook (1988), Kozinets (2008), Levy (1981), Zaltman (2003), and Zhao and Belk (2008), among others, albeit Frye is often foregone in favor of equally profound thinkers like Joseph Campbell, Carl Jung, Roland Barthes, Algirdas Greimas, Claude Lévi-Strauss, or the id-meister himself, Sigmund Freud.

Another popular explanation is palliative. On the basis of Lévi-Strauss's (1963) contention that the function of myth is to mitigate and ideally resolve the contradictions and paradoxes of human existence, this attributes consumer myth-choices to macro social, economic, demographic, and technological developments (Holt 2002, 2004, 2005; Thompson 2004). As consumer culture shifts and fractures under the strains of creatively destructive late capitalism, people require assuasive identity myths and acquire the brands, or procure the experiences, that best articulate them. These offer succor at times of stress, anxiety, and existential angst (Belk and Costa 1998; Holt and Thompson 2004; Kozinets 2002; Thompson and Tian 2008) and are elevated in turn to iconic standing alongside equivalent idols of popular culture-politicians, sportspeople, musicians, movie stars, and so on (Holt 2004).

Above and beyond the myths-are-salves explanation is the myth-as-salvation interpretation. This is predicated on consumers' para-religious pursuit of individual and collective identity projects, which are consecrated through mythimbued brands and devotional consumption practices (Arsel and Thompson 2011; Kozinets and Handelman 2004; Muñiz and Schau 2005; Schouten and McAlexander 1995). Such self-sanctifying consumer actions are not without tribulation (Giesler 2008, 2012; Luedicke, Thompson, and Giesler 2010; Thompson, Rindfleisch, and Arsel 2006). They are mediated, manipulated, and magnified by marketing intermediaries, moreover (McAlexander, Schouten, and Koenig 2002; Peñaloza 2001; Thompson and Tian 2008). But, for many myth missionaries, secular consumer behavior is biblical at bottom (Belk, Wallendorf, and Sherry 1989). Whereas mundane brands offer reasons to buy, transcendent brands such as Apple, Hello Kitty, and Harley-Davidson supply reasons to believe.

Closely associated with these myth-match processes are "geotemporal" considerations (McAlexander et al. 2002, 41). Myths are metamorphoric. They transmogrify through time as they shape, and are shaped by, consumer adoption and abandonment (Bamossy 2005; Holt 2005; Scott 2005). Whether it be myths of manliness (Holt and Thompson 2004), freedom (Peñaloza 2001), progress (Kozinets 2008), wellbeing (Thompson 2004), femininity (Diamond et al. 2009), beautification (Giesler 2012), cosmopolitanism (Thompson and Tambyah 1999), fashion consciousness (Thompson and Haytko 1997), consumer lifestyle (Üstüner and Holt 2010), or drinking milk in Denmark (Kristensen, Boye, and Askegaard 2010), the weight of history impacts consumer action. Geography is significant too, since stellar myths tend to shine in certain settings. Powerful myths are emplaced, even if that place is imaginary (Cayla and Eckhardt 2008), symbolic (Üstüner and Thompson 2012), or virtual (Kozinets 2001). More often than not, they are grounded in locales that are as site specific as the mythological traditions of Ancient Greece or Pharaonic Egypt or Native North America from 
Coyote to Quetzalcoatl. Resonant myths are rarely parochial, though. They express the universal in the local, the general in the particular (Sherry and Schouten 2002).

It follows, for certain consumer researchers, that the most exceptional consumer myths are found in geographically and temporally circumscribed contexts like the Mountain Man rendezvous (Belk and Costa 1998), the Burning Man festival (Kozinets 2002), Denver's annual stock show (Peñaloza 2001) or Harley-Davidson HOG fests (Schouten and McAlexander 1995). This may be so, but especially singular myths are also singularizable. That is to say, they can be felicitously adapted to consumers' individual and collective preferences, aspirations, imaginings. They are blank canvases, near enough, which permit consumers to paint their personalized masterpieces (Holt 2004, 68) or, as Thompson and Haytko (1997, 39) put it, "negotiate a common understanding from countervailing meanings and ideological positions." Iconic brands, analogously, are not set menus of product benefits or user associations, let alone unique selling propositions (USPs), but appetizing buffets that can be picked and mixed as consumers see fit (Holt 1995, 2002; Scott and Maclaran 2013). If not quite all things to all people, the most meaningful myths offer many things to many people (Peñaloza 2001). By allowing consumers to see what they want to see, they enable them to be what they want to be (Diamond et al. 2009).

The malleability of powerful consumer myths is due, we posit, to their imprecision, their amorphousness, their ambiguity. As Ruthven $(1976,1)$ rightly observes, "Myths . . . are obscure in origin, protean in form and ambiguous in meaning. Seemingly immune to rational explication, they nevertheless stimulate rational enquiry, which accounts for the diversity of conflicting explanations." Barthes $(1973,129)$ goes even further, stressing that myth is "not at all an abstract, purified essence; it is a formless, unstable, nebulous condensation . . . an unlimited mass of signifiers." Although the equivocal character of consumer myths has been noted by numerous researchers (e.g., Bamossy 2005; Belk and Costa 1998; Cayla and Eckhardt 2008; Holt 2002; Peñaloza 2001; Thompson and Tambyah 1999; Thompson and Tian 2008), the nature of myths' "constituent ambiguity" (Barthes 1973, 134) remains unclear. Like iconicity (Holt 2004), technology (Kozinets 2008), and morality (Luedicke et al. 2010) before it, ambiguity is ripe for unpacking. Unlike iconicity, technology, and morality, however, this "untheorized background factor" (Luedicke et al. 2010, 1017) is viewed with misgiving in conventional marketing and consumer research.

\section{AMBIGUITY UNPACKED}

Defined by the Oxford English Dictionary $(O E D)$ as "a state of doubtful meaning; uncertain, equivocal, obscure," ambiguity is generally regarded as something to be eradicated rather than embraced. In the brand management literature, for example, clarity, consistency, and coherence have long been highly prized, ambiguity less so. From Rosser Reeves's (1961) USP, which states that successful branding involves a single, clearly expressed claim or concept that is striking and easy to remember, through Ries and Trout's $(2001,8)$ positioning paradigm, which advises brand managers to "jettison the ambiguities, simplify the message, then simplify it some more," to Kevin Lane Keller's (1999) contention that lucidity is essential when building strong, favorable, and unique consumer associations, ambiguity is considered inimical to brand longevity (Aaker and Joachimsthaler 2009; Pearson 2011).

In the advertising literature, likewise, studies show that ambiguity is commonplace (Goldman and Papson 1996; Ha and Hoch 1989) - Peracchio and Meyers-Levy (1994) report that $44 \%$ of ads include ambiguities-but largely because its elimination is rewarding for consumers (McQuarrie and Mick 1992, 1996; Meyers-Levy and Malaviya 1999). That is to say, the pleasure of getting the pun or play on words, or simply resolving the puzzle, enhances processing, elaboration, arousal, and affect generally. True, some consumers are more tolerant of ambiguity than others (Kahn and Sarin 1988). However, experimental studies of lotteries (Kahn and Meyer 1991), loyalty programs (Bagchi and Li 2011), skin lotions (Muthukrishnan 1995), and several other product categories from restaurants to automobiles (Lee and Suk 2010), indicate that, when it comes to ambiguity, less is more for consumers and managers alike. "Hated alternatives," one study crisply comments, "have greater attribute ambiguity than loved alternatives" (Gershoff, Mukherjee, and Mukhopadhyay 2007, 499).

Ambiguity's qualm-inducing capacity is partly attributable to its association with polysemy, a knotty semantic issue that thinkers have attempted to untie since Aristotle (Dimofte and Yalch 2007; Ravin and Leacock 2000). Although the terms polysemy and ambiguity are often used synonymously (Hoch and Deighton 1989; Kleine and Kernan 1991) - and occasionally in combination (McQuarrie and Mick 1992; Ritson and Elliott 1999) — they are not the same. Polysemy refers to words (texts, images, etc.) with more than one meaning, whereas ambiguity obtains when the meaning (or meanings) is unclear. The word "coke," for example, is polysemous, insofar as it can refer to a carbonated beverage, the recreational narcotic, a distillate of coal, or the core of an apple. Ditto the word "it," which is accorded eight separate meanings in the $O E D$, not including the familiar abbreviation of Italy and acronym for information technology. The expression "Coke Is It," on the other hand, is ambiguous, because the pronoun's referent is unclear. As Bryan Dyson observed about his company's brilliantly enigmatic slogan-cum-jingle, "the lyrics intentionally didn't say exactly what 'it' was . . . we should not be too precise, too descriptive or too literal" (Pendergrast 1993, 336). The same is true of equally Delphic taglines like "Just Do It," "I'm Lovin' It," and "Because You're Worth It" (Puntoni, Schroeder, and Ritson 2010).

Another "ambiguity-crushing" factor (Kozinets and Handelman 2004, 699) is the scientific mind-set of marketing and consumer research (Hunt 2002). According to I. A. Richards (1929), the founding father of literary theory (Ea- 
gleton 1983), there is an elemental distinction between scientific language and literary language. Science aspires to linguistic clarity, precision, specificity, accuracy, and exactitude; literature sets great store by richness, variety, allusion, equivocation, and plurivalence. Scientists minimize meaning, poets maximize and, since consumer research leans toward the former, the latter is held in lower esteem. Ambiguity, nevertheless, is central to the literary worldview. It is the pith and pelf of poetry's power (Sherry and Schouten 2002). For those of an artistic disposition, it is something to be admired, applauded, and, not least, analyzed by appropriate literary methods. Or as Graff $(1995,164)$ puts it, "In the criticism of the mid-twentieth century, this tendency to define literature as the opposite of science led to the theory that 'ambiguity' of meaning is a distinguishing feature of good literature. . . . Whereas ambiguity may be a fatal defect in a laboratory report or an accounting ledger, it is a necessary and valuable attribute in a literary work."

The school of thought that Graff is referring to is the New Criticism. Led by John Crowe Ransom and Robert Penn Warren, New Critics rejected biographical, psychological, and historical explanations of literary meaning for detailed line-by-line explications of individual poems, a process known as "close reading" (Davis 2008; Stern 1989). They focused on the words on the page, excavating layers of meaning, identifying the incongruities, noting the contradictions, and teasing out the ambiguities that were the starting point for subsequent, even more radical, schools of literary criticism like reader-response and poststructuralism (Lentricchia 1980).

Of all the alleged New Critics, the one most closely associated with ambiguity is William Empson. His landmark work, Seven Types of Ambiguity (Empson 1930), was once widely regarded as a masterpiece of explication, the literary equivalent of splitting the atom (Haffenden 2005). Despite its title, however, Seven Types of Ambiguity is far from systematic. Empson's seven types are not clear-cut, let alone individually identified. His virtuoso demonstration of close reading, nevertheless, reveals that ambiguity is ubiquitous; it underpins puns, metaphors, allegories, and more. He also shows that there is a spectrum of ambiguity, which ranges from simple confusion or vagueness, through clever contradiction or paradox, to complex cumulation or accretion, where multiple layers of divergent meaning are discernible. Beneath its ambivalences and imponderables, in other words, Empson's book contains a nascent typology, an incipient classification that can be used to unweave the rainbow of ambiguity and thereby identify its colorful components (Dawkins 1998).

For all its literary idiosyncrasies, Empson's tripartite typology is applicable to myth-imbued brands. Myths, as previously noted, are inherently ambiguous (Barthes 1973, 171), as are iconic brands that resonate with consumers (Cayla and Eckhardt 2008; Diamond et al. 2009; Holt 2004, 2005). If anything, branding has become increasingly ambiguous through time (Bengtsson and Ostberg 2006; Heding, Knudtzen, and Bjerre 2009). Originally focused on fast- moving consumer goods (FMCGs) and similar staples ( $\mathrm{Si}$ vulka 2011), branding's domain has become ever more diffuse (Bastos and Levy 2012). The term is nowadays applied to hospitals, universities, art galleries, police forces, political parties, utility suppliers, religious denominations, rock bands, sports teams, movie stars, and, according to Muñiz and Schau (2005), almost everything in contemporary consumer society-dirt, diseases, and disasters included (Ebeling 2010; Fanning 1999). Its mounting semantic entropy is also attributable to the rising tide of cocreative brand communities (Fournier and Avery 2011), proprietorial consumer tribes (Cova, Kozinets, and Shankar 2007), postmodern advertising agencies (Kates and Goh 2003), story-spinning management consultants (Salmon 2010), and academicians' cacophonous contributions to the branding conversation (Thompson, Arnould, and Giesler 2013). The upshot is that the domain, the discourse, the documentation of branding has become much more indefinite, more nebulous, more ambiguous than before. It is ripe for close reading (Stern 2006). It is fodder for literary criticism (Twitchell 2004), and-as this article shall show-Empson's titanic typology can be adapted accordingly.

Indeed, at a time when branding is akin to an enormous luxury liner steaming ever-faster into an ocean of equivocality, Empson's encompassing conceptualization provides an appropriate and necessary steering mechanism. It is a mechanism that $(a)$ helps explain why certain consumer myths resonate, $(b)$ helps unpack the appeal of particularly iconic brands, $(c)$ helps deconstruct the dominant discourse of ambiguity in our discipline, and $(d)$ helps raise a flag for literary criticism at the stern of consumer research. This article plots a course from philosopher John Gray's (2013, 130) assertion that "any system of ideas that aims to be clear and self-consistent breaks down in ambiguities and contradictions," to literary critic Karen Armstrong's (2005, 3) contention that "myth is nearly always rooted in the experience of death and the fear of extinction." Although several crowded routes through consumer mythopoeia exist-archetypal, remedial, spiritual, geotemporal-we take the less busy sea-lane of ambiguity.

\section{TITANIC TALES}

The keel of Titanic was laid on March 22, 1909 (Ward 2012). Twenty-two months later, the iconic White Star liner was launched from Slipway 3 at Harland \& Wolff shipyard in Belfast, Ireland (Eaton and Haas 2011). At the time, Titanic was the largest moving object on earth and one of the most technologically advanced (Johnston 2008). It was also the last word in luxury, a floating grand hotel, whose second- and third-class accommodation was on a par with first and second class elsewhere. If not quite the "ship of dreams" mentioned in James Cameron's blockbuster film, RMS Titanic was a mechanical work of maritime art (Davenport-Hines 2012).

After 10 months' fitting out in Belfast, Titanic sailed for Southampton on April 2, 1912 (Wilkinson and Hamilton 
2011). Although its maiden voyage had been delayed by a coal strike and an accident to its sister ship, Olympic, whose repairs held up work at Harland \& Wolff, Titanic finally cast off at noon on April 10. The luxury liner picked up 274 passengers in Cherbourg, France, and, after collecting 120 more in Queenstown (Cobh) on the southern tip of Ireland, it steamed off to New York on April 11. On Sunday 14th, Titanic's wireless operators received numerous ice warnings from nearby ships, including the Californian, which stopped for the night rather than sail into an ice field. Some but not all of these warnings were passed on to Captain Smith, since the operators were employed by the Marconi Company, not White Star, and spent most of their time sending frivolous messages from first-class passengers to their acquaintances on shore (Matthews 2011).

Titanic steamed ahead, equally frivolously, confident it could cope with the inclement conditions. . . . As everyone knows, Titanic couldn't. Hampered by an uncharacteristically flat calm - which made icebergs harder to see at night, because breaking waves at the base would indicate position and magnitude - the lookouts failed to spot a large iceberg looming right ahead. Despite desperate attempts to take evasive action, the ship received a glancing blow from the berg. It was 11:40 p.m. Less than 3 hours later, Titanic sank beneath the freezing waters of the North Atlantic. There were insufficient lifeboats to accommodate 2,026 passengers and crew, and many boats were launched less than full. Approximately 1,500 people died that night, mainly from hypothermia, though there were dramatic differences in the survival rates of the shipboard classes (Maltin and Aston 2010). All 705 survivors were picked up by the Carpathia, which had steamed to the rescue at dangerously high speed. They were taken to New York City, where an official inquiry was immediately launched into the unthinkable sinking of the unsinkable ship (Wade 1986).

Even by then, though, many of the myths and legends surrounding the leviathan had hardened into the narrative that's been recycled ever since (Biel 2012; Heyer 2012; Howells 2012). Whether it be the fable of Captain Smith urging panicking passengers to "Be British!" before going down with his ship, or the scurrilous story of Bruce Ismay, the chairman of White Star Line, who escaped on a lifeboat while dressed as a woman, the lore of the Titanic is inexhaustible (Wade 1986). Within weeks of the sinking, movies, songs, poems, and books about the calamity were in circulation, and macabre memorabilia were on sale, most notably a black teddy bear by Steiff. The shock waves reverberated for decades in cities like Southampton, where most of the crew resided, Belfast, where the allegedly unsinkable ship was built, and New York, which lost numerous eminent citizens, including Astor, Straus, and Guggenheim (Barczewski 2004). All erected Titanic memorials in due course, as did many other places, including Liverpool, Halifax, Queenstown, and Washington, DC. All were determined never to forget that fateful night (Hammond 2004).

Inevitably, the Titanic soon was forgotten, as the twentieth century rolled on and its catastrophes accumulated (Foster
1997). The unsinkable brand, nevertheless, resurfaced during the 1950s, thanks to a bestselling book by an advertising copywriter for JWT, Walter Lord (1955). Lord's breathless retelling of the steamship's story was made into an enormously successful British movie, A Night to Remember. The Titanic picked up further steam when Robert Ballard discovered the wreck in September 1985; Ballard's dramatic undersea photographs triggered a spate of touching remembrance, tasteless scavenging, and lucrative touring exhibitions by the salvors-in-possession (Ballard 1995). The momentum increased a decade later when James Cameron's prodigiously expensive movie of the tragedy-widely expected to sink without a trace on release-not only triumphed at the box office, with worldwide receipts of $\$ 1.8$ billion, but bagged a record haul of 11 Oscars, including Best Picture (Lubin 1999; Studlar and Sandler 1999).

Top speed, however, was reserved for the centennial celebrations of 2012. And nowhere was the frantic fanaticism for all things Titanic, noted earlier, more apparent than in Belfast, Northern Ireland. A striking, six-story, steel-clad, star-shaped, staggeringly expensive commemorative center has been constructed beside the original slipway, graving dock, and drawing office of the "most famous ship built since Noah's Ark” (Cameron 2011, 11). The centerpiece of a riverside regeneration project, Titanic Belfast showcases the immemorial vessel, with artifacts, replicas, interactive displays, and innovative dark ride technology. Constructed to the same dimensions as the original liner, the city's Signature Building may or may not be the biggest brand museum on earth but, according to its general manager, Titanic stands proud as one of the world's five foremost brands (Kinkade 2011).

\section{METHODOLOGICAL PREMISES AND PRACTICE}

Although Apple, Google, Coca-Cola, and other companies would doubtless disagree with the center manager's bold claim, Titanic's iconic status is incontestable, as is its perennial consumer appeal (Heyer 2012). Yet the reasons for this fascination remain moot, despite a century of debate and discussion. In his introduction to Robert Ballard's bestselling account of the discovery of the wreck, for example, Walter Lord (1995) tries to explain Titanic's incredible hold on the world's imagination. Its abiding mystique, he ventures, is attributable to the elements of Greek tragedy, epic, myth, and legend that are integral to the steamship's story: the sheer scale of the disaster, the hubristic proclamation of its unsinkability, the nemesis of Mother Nature's iceberg, the warnings that went unheeded, the in-built morality tale about pride coming before a fall, the symbolism of a monster ship that mirrored the social stratification of the vainglorious Gilded Age, and the very name of the majestic vessel, a prodigious instance of myth writ large (Lord 1986).

What Lord doesn't mention is Titanic's status as an open, "writerly" text, which is amenable to all sorts of idiosyncratic, individualized readings (Barthes 1990). The steam- 
ship, many commentators make clear (Heyer 2012; Howells 2012; Studlar and Sandler 1999; Wade 1986; Ward 2012), has something for everyone, whether they're mystics, moralists, metallurgists, memorabilia collectors, maritime enthusiasts, manipulators of political, social, and cultural agendas for ideological/commercial purposes, or-in our own case-myth-minded analysts of textual ambiguity.

Accordingly, this empirical investigation of Brand Titanic is predicated on the close-reading principles of literary criticism and the premises of CCT more generally. The former were pioneered by Barbara B. Stern, who began as a New Critic and subsequently applied several schools of "lit-crit" to consumer concerns (Stern 1989, 2006). In so doing, she did much to establish literary criticism as a legitimate approach to qualitative consumer research. According to Arnould and Thompson (2005), the interpretive pirouettes of literary theorists - as performed, for example, by Schouten, Durgee, Sherry, Scott, Holt, Mick, McQuarrie, Escalas, and others - are central to the CCT program, specifically the "mass mediated marketplace ideologies and consumers interpretive strategies" subdivision, which focuses on the texts and artifacts of popular culture.

As an iconic artifact of popular culture, Titanic is perfectly suited to the CCT treatment. Researching iconic brands from a literary/cultural perspective is an eclectic undertaking, however (Cross and Gilly 2012; Schroeder and Salzer-Mörling 2006). It involves archival endeavor and empirical investigation (Holt 2004). It necessitates the examination of participants' narratives-which are authored by several interested parties, principally brand owners, brand consumers, brand influencers, and the creators of cultural representations (Holt 2003)—while remaining sensitive to the wider social, economic, and technological developments that shape the stories stakeholders tell (Holt and Thompson 2004). It is a qualitative methodology that does not aspire to generalizability (except in the liberal arts sense, whereby wider resonance or meaning can be found in an individual work) but strives to use brand-specific data to illuminate broader aspects of consumer culture.

Brand Titanic can be plumbed with profit from this CCT perspective. In order to do so, the authors combined empirical data gathering and archival research in the RMS Titanic repository. Representatives of all four authors of the brand story were contacted and questioned over a 5-year period. A mixture of qualitative methods was employed, in keeping with established cultural research conventions (Hackley 2003). These included introspective essays (74), focus groups (4), long interviews (9), netnography (1), and participant observation at Titanic-themed exhibitions, museums, memorials, guided tours, and fund-raisers (8).

Of the four principal brand authors, most data were gathered from consumers (mainly Irish but also French, German, Spanish, and American). The brand owners were also interviewed, and, while Harland \& Wolff no longer builds ships from scratch, it continues to sell Titanic memorabilia and takes a proprietorial interest in the wreck (Pellegrino 2012). A selection of key influencers-specifically, spokes- persons for tourism, property development, public relations, movie making, historical preservation, and the marketing of Belfast's Signature Building-was questioned about their involvement with the brand. Popular cultural representations of the unsinkable ship (in movies, novels, photographs, oral histories, newspaper articles, television documentaries) were collated and content analyzed, as were extant anthologies of Titanic's cultural impact (Biel 2012; Foster 1997; Howells 2012). Archival research at the Public Records Office, Belfast, which holds a large Titanic collection, was supplemented with digital data gathering exercises. These ranged from website monitoring and e-interviews to a "passive" netnography (Kozinets 2010) of comments posted on Titanic-related media stories.

In practice, our research program evolved through four overlapping phases. It commenced with 3-years' intermittent work in the Titanic archive, coupled with background reading, exhibition attendance, and family history excavation. (The lead author's great-grandfather helped build RMS Titanic, both his father and grandfather worked for Harland $\&$ Wolff, and a great-aunt owns several authentic items of Titanica.) The second phase comprised content analysis of relevant cultural representations-movies, novels, cartoons, computer games, and so on-plus the passive netnography, which continued throughout the study. The third phase involved empirical data gathering, specifically introspective essays from groups of undergraduate and postgraduate students, who comprised an eclectic mix of ages, genders, ethnic affiliations, and feelings for Titanic, both pro and anti. The final phase, which coincided with the centennial commemorations, consisted of depth interviews and focus groups with a broad spectrum of stakeholders, noted above, coupled with site visits to Titanic Belfast, at both peak and off-peak times.

All told, our data set consisted of approximately 1,200 A4 pages of written text, along with associated photographs, videos, artworks, and ephemera. These were analyzed with the aid of Empson's ambiguity-oriented approach to literary criticism. It is necessary to note, though, that unlike ethnographic or grounded theory techniques of qualitative inquiry, which presuppose that meaningful constructs eventually emerge from researcher engagement with the raw data, literary procedures are impositional, inasmuch as texts are investigated with intent (Eagleton 1983). That is, they are apprehended from a preordained critical position, be it Marxist, feminist, psychoanalytical, postcolonial, reader-response, Empsonian, or whatever. This does not mean that literary methods are rigid or doctrinaire, since a flexible, iterative, back-and-forth interpretive process prevails in practice. However, they do approach the data from a top-down perspective rather than a bottom-up manner. They are the liberal arts equivalent of deductive reasoning and although inductive approaches predominate in CCT, deduction is not unknown (Giesler 2008, 2012; McQuarrie and Mick 1996; Mick and Buhl 1992; Stern 1995; Thompson 2004).

It is also important to stress that, compendious as it is, our data set is far from comprehensive. Given the staggering 
amount of secondary material that is available, not least on websites like Encyclopedia-Titanica and Titanic-Titanic, it comprises the merest tip of the iceberg. We have nevertheless endeavored to combine the in-depth-interviewing and deep-immersion-across-multiple-sites models of data gathering. We have incorporated a historical dimension, in accordance with Arnould and Thompson's (2005) recommended research agenda. We have delved into the digital domain of netnographers, albeit for supplementary rather than primary research purposes. We have sought, what's more, to cover all four brand author bases identified by Holt (2003), most notably the tainted brand behind the Titanic brand, Harland \& Wolff, which has been at the center of the shipshaped cultural complex for a century and counting.

\section{AMBIGUOUS FINDINGS}

McCracken $(2005,2012)$ maintains that brands are complex things whose multitudinous meanings are often unclear or unfathomable (Cayla and Eckhardt 2008; Giesler 2008; Holt 2002, 2004; Stern 2006; Thompson and Arsel 2004). The depth of this unfathomability can be better understood, if not completely plumbed, by William Empson's (1930) typology of ambiguity. The seven types, as we have noted, are not autonomous, but it is nevertheless possible to identify a spectrum of Titanic ambiguities, from confusion though contradiction to cumulation.

\section{Confusion}

Whatever else is said about RMS Titanic, its unique selling point is incontestable: the unsinkable ship that sank. This concision, nevertheless, belies the confusion, the vagueness, the nebulousness that surrounds the epic vessel. Howells (2012) contends that almost every aspect of the sinking, apart from the timing of the iceberg strike (11:40 p.m.) and the stern section's final plunge $(2: 20$ a.m.), is muddled at best and misleading at worst. Despite three official enquiries, there is no consensus on the causes of the accident-excess speed, bad workmanship, flawed design, corporate complacency, unusual weather conditions, failure to heed ice warnings, refusal to fit sufficient lifeboats, absence of binoculars in the crow's nest, sheer bad luck and so on-which has led to endless debates about the details of the disaster ( $\mathrm{Ti}$ tanic-Titanic 2000). Did the band play "Nearer, My God, to Thee" at the end and if so which version? Were steerage passengers locked below decks or denied access to the lifeboats? Did the Californian ignore Titanic's distress flares or was there a "mystery ship" in between them? Were panicking passengers shot by first officer William Murdoch, who then took his own life? Did Sir Cosmo Duff Gordon bribe the seamen on board Lifeboat One, with a view to standing off and staying safe rather than returning to rescue the dying? Did the stricken ship split in half or sink in one piece, as was widely assumed at the time (Maltin and Aston 2010)?

Added to all this is the confusion caused by the basic layout of the ship (which was a labyrinthine maze of cor- ridors, stairwells, and bulkheads), the confusion on board during the loading of the lifeboats (as the regulation safety drill wasn't conducted, no one really knew what to do), the confusion caused by the band's sprightly playing of upbeat ragtime standards (many underestimated the seriousness of the situation as a result), the confusion passengers felt when first ordered to abandon ship (most were reluctant to leave a large, warm, well-lit luxury liner for a tiny lifeboat on the cold, dark North Atlantic), the confusion among passing ships when they discovered Titanic was in trouble (the Californian thought its distress flares were fireworks), the confusion back on shore when news of the sinking broke (initial reports suggested everyone survived and the damaged vessel was being towed to Halifax), the confusion over who died and who survived (due to typographic errors in the bulletins issued by White Star Line), the confusion surrounding the total number of people on board (which is still not settled, despite decades of investigation) and, most incredibly of all, the confusion about where the wireless-equipped liner actually went down (the wreck was found 15 miles from its last broadcast position).

All of these unfathomable issues have been compounded and perpetuated by a century's worth of cultural representations (Foster 1997), not least the public enquiries which were characterized by conflicting eyewitness testimony, at least some of which was deliberate White Star misinformation (Lightoller 1935). First officer Murdoch's portrayal in Cameron's Titanic, for example, caused a storm of controversy in the Scottish sailor's home town (Barczewski 2004), as did the stereotyped depiction of Irish emigrants in steerage, who were "riverdancing as the ship went down" (Donnelly 2004), as did the insinuation that Titanic was badly built, since its sister ship, Olympic, had a long, successful, accident-free life and was known as Old Reliable (Johnston 2008):

When oh when are people going to stop banging on about design faults? If the design was lethal, then how come her sister ship the Olympic sailed for years across the Atlantic before being scrapped? They were the same basic design after all. (Diddleypete, netnography)

Nor should we forget the myths that cling to the iconic brand like limpets (Heyer 2012; Howells 2012; TitanicBerg 2007). According to The-Titanic.com (2011), these include: the myth of proclaimed unsinkability (no such boast was made by its builders), the myth of the speed record attempt (Titanic wasn't designed to capture the Blue Riband), the myth of women and children first (on the starboard side, yes, on the port side different disembarkation policies disastrously prevailed), the myth of stiff-upper-lipped stoicism as the ship slipped under (disbelief, followed by denial, followed by shambolic disorganization, followed by mass panic was closer to the mark), the myth that Titanic broadcast the first S-O-S signal (the Marconi operators commenced with old distress call, C-Q-D, then switched to its nascent replacement, S-O-S, though they weren't the first to send that signal), the myth of an unquenchable inferno 
which raged below decks throughout the voyage (perfectly true, but it smoldered rather than raged and fires-in-the-hold weren't unusual back then), and the myth that Robert Ballard's expedition to the wreck was a front for covert CIA activity at the height of the Cold War (it was actually a US Navy-funded investigation into the 1960s' sinking of two nuclear submarines).

So abundant are the confused and confusing fallacies surrounding Titanic that an entire genre of tie-in texts, dedicated to debunking the misconceptions, now exists (Maltin and Aston 2010; White 2011). Likewise, most exhibitions attended as part of our empirical research program include interactive displays concerning the myths and mistaken impressions that continue to circulate, despite decades of detailed investigation:

Finally, we get to the ninth gallery, which is devoted to the aftermath of the sinking and its impact on popular culture. There's a computerized quiz about the myths and legends. It's proving very popular, with a long line of rubbernecking people eager to pit their wits against the machine and, presumably, separate fact from fiction. I patiently wait, quietly confident that I know all there is to know about Titanic. I wonder if there is a prize for those who get every question right. I play. I get two wrong. I thank heaven a klaxon didn't go off when I erred so embarrassingly. I slink out of the gallery muttering imprecations about Bruce Ismay. How am I supposed to know what he did with the rest of his life? Who cares that his frickin' racehorse won the Derby? (Researcher field notes)

When asked about the misunderstandings, moreover, the marketing manager of Harland \& Wolff rolled his eyes and shook his head. He'd been approached by many misinformed reporters and television producers with spurious theories to prove, whether it be the substandard workmanship of his forebears or the yarn that Titanic and Olympic were swapped surreptitiously as part of an elaborate insurance scam:

Informant: I'm sure you know the myth of the insurance swindle. Well, we have concrete proof that Titanic and Olympic weren't swapped. The fixtures and fittings of the Olympic were sold to a hotel in the northeast of England [the White Swan Hotel, Alnwick, Northumberland]. A few years ago, we refurbished them and when we removed the wooden paneling the works number on the back was 400 , not 401 .

Interviewer: 400 being Olympic and 401 Titanic.

Informant: Exactly. There was no secret switchover, no insurance plot hatched by White Star. The nonsense that some people talk about Titanic. You wouldn't believe what I hear in here. It got so bad that we produced an education pack. It explains the facts and tells the true story of Titanic.

Interviewer: So, you've cured the problem?

Informant: No. No. The problem can't be cured. People believe what they want to believe. The pack doesn't make much difference. There's no telling them. (Sales and marketing manager, interview)

Speculating on the basis of incomplete knowledge or halfdigested information is de rigueur in Titanic circles (Pellegrino 1990, 2012). Everyone, near enough, is happy to hazard a hypothesis, posit a supposition, indulge in conjecture, or make an educated guess about the great ship's sinking and the imponderables that wallow in its wake. "What if" are probably the two most overused words in Titanic discourse (Foster 1997): What if they'd rammed the iceberg head-on instead of exposing the liner's vulnerable flank? What if the final ice warnings had been delivered to the bridge rather than placed under a paperweight in the radio room? What if the engines hadn't been thrown into reverse, which rendered the rudder less effective than it could have been? What if the radio operator on Californian had picked up the initial distress signal instead of going to bed 10 minutes beforehand? What if the iceberg had damaged four watertight compartments, which was survivable, instead of five, which condemned Titanic to its doom? What if Robert Ballard had been beaten to the wreck by a less articulate, charismatic, media-friendly oceanographer, as he almost was? What if James Cameron had cast Gywneth Paltrow and Matthew McConaughey as Rose and Jack, respectively, as he almost did? What if Leonardo DiCaprio, a self-consciously serious actor, had rejected the teen-idol role, as he almost did?

What, indeed, if the Titanic hadn't foundered? Would anyone even remember its name, never mind attend the exhibitions, acquire the collectibles, or make advance bookings on Titanic II, an exact replica currently under construction in China and expected to weigh anchor come 2016 (Sheridan 2013)?

\section{Contradiction}

If confusion or vagueness comprises one pole of the ambiguity spectrum, contradiction or paradox represents the other. In literary circles, paradox is regarded as a particularly powerful figure of speech, because it consists of two opposing sentiments in a single statement. For New Critics like Cleanth Brooks $(1968,1)$, "the language of poetry is the language of paradox." Nowadays, of course, many tend to treat paradox in more prosaic terms, as clever wordplay of the "toxic assets," "friendly fire," "negative growth," "love to hate" variety (Johnson 2011). As noted earlier, however, contradiction lies at the core of consumer myth-making and outstanding branding (Arsel and Thompson 2011; Holt and Thompson 2004; Kozinets 2008; Mick and Fournier 1998; Peñaloza 2001; Thompson 2004; Thompson and Arsel 2004). It is an iconic brand's ability to resolve the contradictions of consumer culture that raises it above run-of-themill competitors (Holt and Cameron 2010).

Contradiction is integral to Titanic culture. The sinking of the unsinkable is itself a contradictory notion, as are watertight compartments that aren't, as is the Titanic's original status as a nondescript ship. Up until its sinking, Titanic was regarded as unremarkable compared to its big sister and 
alpha predecessor, Olympic, which was launched the year before to enormous worldwide publicity (Johnston 2008). The backup vessel, by contrast, put to sea with comparatively little fanfare or awestruck media attention. In truth, Titanic's high-speed transatlantic dash was designed to generate the press attention that had been largely absent up to that point (Ward 2012). At the time, Titanic was just another enormous White Star steamship, the second of three "Olympic class" carriers:

You know, Titanic was not that significant. Even in its day. Titanic was the second of its class, the Olympic class. It was not that big a deal. The Olympic was the important one, a step change. Olympic was the greatest ship of its day, not Titanic. When Olympic was launched, it was painted white so that it would look good in photographs and publicity. The Titanic wasn't. All that stuff you read that Titanic was a wonder of the world. It wasn't. Well, it was. But not really. Not back then. (Sales manager, interview)

Titanic may not have been a big deal at the time (albeit photographs and newspaper reports in the archive indicate its launch was far from insignificant) but it is undeniable that many benefits flowed from the greatest new product failure in history, paradoxical though this appears (Biel 2012). Apart from the seafaring benefactions that the sinking precipitated-changes to lifeboat regulations, permanent North Atlantic ice patrol, round-the-clock wireless communications, international agreement on distress signalsit's clear that many individuals and institutions gained by association with the steamship (Heyer 1995, 2012). The Marconi wireless system benefitted enormously from its starring role in the sinking, as did David Sarnoff, the radio operator who parlayed his bit part into a stellar career at RCA. The New York Times, a third-rate rag at the time, established its reputation as the newspaper of record thanks to its accurate reporting of the unfolding tragedy. J. J. Astor, the richest man on board and a pariah in American polite society, was redeemed by his self-sacrificing behavior as the leviathan went down. Harvard University got a badly needed new library, thanks to the generosity of an on-board benefactor whose husband and son didn't survive. The "unsinkable" Molly Brown didn't do too badly either, nor did Captain Rostron of the rescue ship Carpathia, who was lionized for the rest of his life, nor did the surviving babesin-arms on board, such as Eva Hart, who were feted in their declining years at Titanic conventions and commemorations. All reaped untoward rewards from the nightmare, what Žižek (2009), discussing Cameron's Titanic, terms the "ambiguity of obscenity," that is, human catastrophe as a blessing in disguise.

James Cameron, lest we forget, also won the ship-shape sweepstake, as did Kate Winslet, Leonardo DiCaprio, and Celine Dion (Lubin 1999). The same is true of salvage teams, auction houses, maritime museums, memorabilia merchants, and itinerant exhibition impresarios, like Premier Exhibitions, Inc., who boast that 25 million paying customers have visited their blockbuster shows in Orlando, Atlanta, Las
Vegas, and elsewhere. Such success, however, has not been without a countervailing consumer backlash:

When people are asked what they think or know about the Titanic, they seem to be able to recount the events which took place in the film, and Celine Dion's name would be mentioned on numerous occasions, due to the smash hit "My Heart Will Go On." This should not be how the younger generation remember or are taught history. Hollywood has taken advantage of the tragedy and has manipulated people into thinking this is the way in which the line of events happened. They are just out to make more money for themselves. They should think of the families and friends of those who died in the tragedy and make a film which they would be proud of, without all the hype behind it and such extensive merchandising techniques. (Jemma, introspection)

Interestingly, Cameron's hugely successful film is often described in contradictory terms (A. Keller 1999; Lubin 1999). It is variously portrayed as an auteur blockbuster, as a romantic disaster movie, as a cinematic rotten tomato that's so bad it's good, as a love to hate combination of old-style movie-making with cutting-edge special effects, as a folly certain to founder on release but which floated instead to the top of the box office, where it docked and dropped anchor, as a movie-theater experience that takes longer to sit through (194 minutes) than the actual sinking of the actual ship (160 minutes)! Cameron's Titanic is contradictory in another sense too, insofar as it represents the usurpation of reality by the fake (Baudrillard 2002). Granted, the realities of the sinking have always been moot-imaginative mythologizing was evident from the very outset, when hard facts about the catastrophe were unavailable-but that is even more apparent today, after a century of speculation, investigation, and representation (Heyer 2012). For the vast majority of our informants, Titanic means the movie, not the historical event. Their interest in the latter is a consequence of the former. Their understandings are cinematically shaped:

\section{Moderator: Are you familiar with the Titanic?}

Group: The movie? Ah, okay. You mean the boat that sank? The movie?

Moderator: Titanic for you is the movie?

Group: Yes, it means Leo DiCaprio . . . (laughs). (French focus group)

Cameron's movie, in a nutshell, has become the baseline for the brand. Nowhere was this better illustrated than by the sinking of Italian cruise liner Costa Concordia in January 2012. Many media reports drew unprompted parallels with the Titanic - Cameron's Titanic - in their accounts of the tragedy, as did the passengers themselves (Hooper and McVeigh 2012). Certain online cynics even suggested that it was a tasteless public relations gimmick to draw attention to the centennial of the sinking:

It beggars belief that such a tragedy should occur 100 years-minus a few months since the horrific 1912 tragedy 
of the April 14 sinking of the Titanic. Could have been a stunt to commemorate the tragedy if it wasn't so real. (JohnHynds, netnography)

Unseemly as this seems, the ultimate paradox perhaps is that when Cameron's blockbuster was rereleased in 3D, to coincide with the centenary of the sinking, many teenage cinema-goers were unaware that the movie was based on a historical event (Daily Mail 2012). Given, though, that no one truly knows what transpired on Titanic that night, despite a century of supposition (Ward 2012), they are virtually right. As Mitchell $(2004,408)$ observes about Titanic in his award-winning novel Cloud Atlas, "The actual past is brittle, ever-dimming and ever more problematic to access and reconstruct: in contrast, the virtual past is malleable, everbrightening and ever more difficult to circumvent/expose as fraudulent."

\section{Cumulation}

Important as confusion and contradiction are to Empson's (1930) typology of ambiguity, his capstone category is cumulation. Citing Gerard Manley Hopkins's Windhover with particular approval, he lauds the poet's unusually rich and resonant literary allusions which contained layer after layer after layer of meaning, not unlike the Russian doll model of narration identified in American Girl (Diamond et al. 2009). The Titanic too is a meanings magnet. Yarns and fables and legends and superstitions have accumulated around the brand like barnacles (Foster 1997). Innumerable movies, musicals, miniseries, documentaries, poems, plays, operas, murals, periodicals, pop songs, museum displays, photographic exhibitions, heritage centers, computer games, light shows and so on, have been conceived or created or curated or composed (Foster 2002). The artwork alone is vast, especially online. There are websites and appreciation societies beyond number. The first film was made less than a month after the sinking and starred one of the survivors. More than 100 Titanic-themed Tin Pan Alley songs were copyrighted in 1912 alone. Over 2,000 books have been published about the steamship, everything from the story of the iceberg to studies of passengers' companion animals (Davenport-Hines 2012). There's a vampire novel set on the rescue ship Carpathia (Forbeck 2012); there's a Sherlock Holmes sequel, where the great detective grapples with Moriarty's vengeful brother on the boat deck (Seil 1996); there's a teenage mutant horror story that treats Titanic as a twentyfirst-century plague ship (Bateman 2007); there are all sorts of heartrending romances, heart-stopping thrillers, and heartfelt family sagas, such as Danielle Steel's (1991) No Greater Love and Louise Patten's (2010) Good as Gold, that use Titanic as a colorful backdrop and its sinking as crude but effective plot device. There are works of hard-core pornography set on the throbbing, pounding, heaving steamship (McCaughan 1998). There is a strangely affecting short story, based on a tabloid headline in the National Enquirer, about the ghost of a Titanic victim trapped for eternity in a waterbed (Butler 1997). There is an equally spooky police procedural that passes caustic comment on Belfast city's commercialization of the catastrophe:

"Look at that," McKenna said, indicating the stretch of land around the cranes. "They're calling it the Titanic Quarter now. Can you believe that?"

Fegan didn't answer.

"There's a fortune being made out of that land. It's good times, Gerry. The contracts, the grants, all that property they're building, and everybody'd got their hand out. But, Jesus, they're naming it after a fucking boat that sank first time it hit the water. Isn't that a laugh? This city gave the world the biggest disaster ever to sail the sea and we're proud of it. Only in Belfast, eh?" (Neville 2010, 20)

And the accumulation doesn't end there. As Ward's (2012) Rough Guide reveals, the calamity is a crucible of conspiracy theories and tall tales. The former range from the aforementioned claim that the sinking was a nefarious insurance scam by Bruce Ismay, which went disastrously wrong, through the unfounded rumor that Titanic was cursed by an Ancient Egyptian mummy in the cargo hold, to the crazy contention that the accident was a Dan Brown-style Jesuit conspiracy led by Father Browne (of Titanic photographs fame). The latter comprise exaggerated narratives, tales as tall as the Titanic itself (Lord 1986). These include everything from the seemingly fanciful story that Harvard undergraduates are required to take a swimming test as stipulated in the will of Eleanor Widener (the survivor who endowed the eponymous library in memory of her bibliophile son, Harry) to the rather more remunerative theory that the Titanic contained a vast treasure trove of gold bullion, silver ingots, precious jewels, and so forth (or, conversely, was ironically transporting a consignment of domestic refrigerators and industrial ice-making machines).

Furthermore, all sorts of eerie premonitions have been reported, albeit some are more believable than others. At one end of the fidelity spectrum is the far-fetched claim that the ship's cat and its kittens perspicaciously disembarked at Southampton (Titanic-Titanic 2000). Somewhere in the middle is the unproven assertion that 55 prebooked passengers had bad feelings about the voyage and cancelled their journeys (Behe 1988). The opposite end is occupied by the incontrovertible fact that Morgan Robertson's 1898 novella Futility tells the tale of a brand-new luxury liner that collides with an iceberg in the North Atlantic en route to New York and sinks with huge loss of life due to a shortage of lifeboats. Fourteen years before the event, Robertson named his fictional steamship Titan (Lord 1955).

Such omens and presentiments are readily dismissed, but the spookiness of the ship is undeniable. Several scientists who have visited the sunken vessel and encountered the socalled ghosts of the abyss (Cameron 2003) report strange, spine-chilling, hair-raising, goose-pimpled sensations (Pellegrino 2012). As indeed do some of our informants:

To think that the remains lay at the bottom of the ocean undisturbed for so long, it's actually quite spine tingling. Seeing footage of it through the diver's cameras, it's hard to 
believe that people were once on board the ship. Seeing bits and pieces still intact, people's possessions lying still is incredible too. It's very eerie looking at the ship under the water, as if it's a ghost ship with many watery souls still on board. (Nicola, introspection)

So weird and wonderful are the "cultural effusions" (Barczewski 2004, xiv) surrounding Titanic that it is difficult to know where the truth stops and fiction starts. In interpretive terms, it is not dissimilar to Geertz's $(1973,29)$ adroit anthropological anecdote about "turtles all the way down," though in Titanic's case it's a bottomless crevasse of mythinformation beneath a fragile ice-bridge of truth (Biel 2012). Thus the legendary conman Titanic Thompson was supposed to have been on board (hence the nickname) but wasn't. The legendary African American boxer, Jack Johnson, was allegedly denied passage by a racist booking agent (who said, “we ain't haulin' no coal") but wasn't. The legendary psychic W. T. Stead predicted the disaster in several short stories (one of which described an encounter between the real life Captain Smith and an iceberg), yet he boarded Titanic anyway and failed to survive its sinking. The legendary fictional character Jack Dawson was a figment of James Cameron's imagination, but the grave of a near namesake in Halifax's Fairview Lawn cemetery is visited by fans of the blockbuster movie, many of whom leave tokens of undying affection (Nash and Lahti 1999).

The Titanic, it appears, is capable of accommodating every first-class fable, second-class yarn, and third-class shaggy dog story that chooses to clamber on board. It also serves as a storytelling crucible for consumers (Shankar, Elliott, and Goulding 2001). A number of our informants' unprompted responses to Titanic comprised adaptations of the tragic archetype (Stern 1995) to their personal circumstances. Some refer to the terrible loss of life that night and relate it to sudden deaths of their loved ones though accident or disease. Some interpret Titanic in professional terms, as an emblem of their ambitions, aspirations, and dashed hopes in unsuccessful attempts to forge careers, build businesses, or attain educational qualifications. Some treat the steamship's story as a "precedent and template" (Bergfelder and Street 2004, 1) for analogous human calamities like 9/11, Hurricane Katrina, the Indonesian tsunami, the Fukushima earthquake, or the oil spill in the Gulf of Mexico. Some turn the tragedy on its head, arguing that Titanic is ultimately inspirational, a necessary reminder to live every day to the full, to make the most of the moment, to count one's many and varied blessings because death and disaster might be lurking right around the corner:

The Titanic was always referred to as the Ship of Dreams, and it is clear it meant different things to different people, and like those people I myself have my own dreams and I hope that I will get everything I want in life no matter how many icebergs there are in the way. It makes me realize that no dream is too small or impossible if you really want it, but there will be times when it will be more difficult than others or seem impossible but you can make it. (Wayne, introspection)

Such consumer interpretations indicate that Titanic is more than a ship that sank or a terrible tragedy. It is an abiding symbol, an encapsulation of the human condition, a morality tale that calls down the ages (Luedicke et al. 2010). More prosaically, it is a story-stoked brand that, according to one public relations consultant, is the narrative equivalent of a perpetual motion machine:

The stories are unending. We have a master plan for the next 3 years, based on brainstorming sessions. But they are selfperpetuating. We have human interest stories, engineering stories, cultural stories, design stories, architectural stories, historical stories, inspirational stories, offbeat stories, quirky things. The stories themselves generate stories, because we get local coverage of the international coverage in Fodor, National Geographic, The Economist, and around the United States generally. There's always something. Always new angles. We're holding stuff back we have so much. It's nonstop. (PR consultant, interview)

\section{BUILT BY THE IRISH, SUNK BY THE ENGLISH?}

In addition to outlining the various forms of ambiguity, Empson (1930) makes clear in his concluding chapter that context is crucial. Ambiguity "must in each case arise from, and be justified by, the peculiar requirements of the situation" (Empson 1930, 235). He likewise notes that ambiguity is metamorphic, inasmuch as meanings change through time. A term that appears ambiguous to latter-day readers may have been wholly unambiguous in days of yore. What's more, the ambiguities of particularly resonant expressions - those that generate multiple interpretations - tend to be released slowly, as readers ruminate on and revisit the works in question. The richer the work, the longer this takes.

If not quite the gift that keeps on giving, ambiguity is affected by situational issues and secular trends, as are the myths where ambiguity abides (Cohen 1969). These "geotemporal" considerations (McAlexander et al. 2002, 41) are powerfully apparent in Titanic's cultural complex. From the very outset, the myths and legends surrounding the unsinkable ship have been inflected by nationalistic and civic sensibilities (Howells 2012). The interpretation of the accident, for instance, was very different on either side of the Atlantic (Wade 1986). For the British, it was a manifestation of admirable sang froid in the face of catastrophe-no panic, dutiful crew, politeness prevailed, orderly queues at the lifeboats. In North America, the entire episode was seen as a shambolic example of English ineptitude, inefficiency, amateurism, arrogance (Biel 2012).

These contrasts, Howells (2012) contends, cannot be divorced from real-politic in general and the respective standing of the great powers in particular: America emerging as an imperial colossus, Britain on the slippery slope of incipient decline. However, they show how the exact same event 
can have different meanings in different places and for different groups of people (Holt 1995; Mick and Buhl 1992; Puntoni et al. 2010). German interpretations of the Titanic tragedy are very different again, not least as a source of wartime propaganda (King 2004), as indeed are Scandinavian interpretations (Björkfors 2004), as are those of the Irish. For Hill (2004), Titanic symbolizes the sociocultural schism that has obtained on the island of Ireland in the century since the sinking. The Titanic was built in Belfast, an industrial enclave of a predominantly agricultural island, by thousands of Irish workmen most of whom were devout Protestants and Unionists. That is, British in outlook and allegiance. If not quite a Protestant ship for Protestant people, Titanic was British to the last bolt and rivet (Foster 1997). The shipyard's employees were exclusively drawn from a single, bitterly sectarian, section of Irish society, even though Catholics comprised $25 \%$ of the local population. The ship was built, what's more, at the height of Ireland's home rule campaign, which agitated for a modicum of independence from British dominion. This prospect filled Ulster Protestants with dread, since they'd be a tiny minority huddled in one corner of a predominantly Catholic island.

Thus the success of Belfast's shipyard-the biggest and best in the world-denoted continuing Protestant ascendency, as did its pride and joy, the most titanic steamship ever built. Accordingly, the catastrophic failure of its single greatest achievement was a devastating blow to Protestant pride (Foster 2002). It was a blow that was reinforced by Irish partition in 1922, when the six northern counties clung on to British citizenship, like beggars at a feast. Further humiliation was heaped on the hubristic city by drastic, Detroit-style industrial decline and a low-level civil war that blighted the final 3 decades of the twentieth century (Neill 2001). The urban rot was only stopped in the aftermath of the Good Friday Agreement of 1998, when the city finally awoke from its sectarian slumbers (Neill 2010).

For most of this period, Titanic was a taboo word (Hill 2004). Harland \& Wolff actively opposed any discussions and/or debates about the disaster, even refusing to accommodate the (Northern Irish) producer of the 1958 movie $A$ Night to Remember, despite his family connections to the firm (MacQuitty 2000). For Foster (1997, 76), Titanic symbolized nothing less than the "thwarted nationhood" of U1ster Protestants: "At the level of community dreamwork, the foundering of the ship and the founding of Northern Ireland were intertwined; the ship became Northern Ireland . . . . but it was always in danger of being sunk by the chillingly impersonal iceberg dynamics of Irish nationalism."

Symbolic ship of state, or not, the simple fact is that Titanic was denied for decades. Meanwhile, the world woke up to its enduring appeal. The remarkable photographs of the wreck by Robert Ballard may have captivated television audiences around the globe but in the north of Irelandthen embroiled in a prolonged spasm of sectarian conflict - the ship still symbolized societal divisions and continuing discrimination against Catholic workers. In her quasi-autobiographical novel, Titanic Town, Mary Costello (1992) recounts an urban legend that the serial number of the ship enshrined anti-Catholic sentiments and how Protestant workmen profaned the Pope as construction progressed. These beliefs are still extant, as our data demonstrate, even though they're entirely without foundation:

\begin{abstract}
My only opinion toward the shipyard it was built in was instilled to me by my father at a young age. This was that it was a predominantly Protestant work force who subjected Catholic workers to beatings and threw them into the water at the docks. Another memory I recalled was the hull number 390904 assigned to the Titanic, if written in longhand and looked at in a mirror read NO POPE. Of course this is just urban legend and not even slightly true. (Martin, introspection)

I asked my father how he felt towards the Titanic. He told me some interesting facts, one of which was that very few Catholics were employed to work on the Titanic or even at the docks at all. "The Titanic was built with only Protestant hands," he says, almost indicating that is why it was such a disaster. (Mairead, introspection)
\end{abstract}

Come Cameron's blockbuster, the release of which coincided with Northern Ireland's return to comparative normality, the Titanic was increasingly seen as an exploitable asset, nothing less than "a unique selling point for Northern Ireland" which "could open the door to thousands of tourists" (Belfast Telegraph 1999, 3). This prospect, along with ensuing grand plans to turn the derelict shipyard into a massive riverside redevelopment project, was initially met with distrust, dismay, and downright disgust (Neill 2006). Money talks, however, and when the expensive apartments, marinas, and recreational facilities started to rise on the site of the old slipways - and the centenary of the sinking appeared on the horizon - the pot of gold at the end of the Titanic rainbow loomed ever larger in civic consciousness. This culminated in a lavishly appointed, $£ 100$ million visitors' center devoted to the unsinkable brand, albeit the ship has been radically reframed and reinterpreted as part of this rehabilitation process. Far from being a disaster, Titanic is now a signifier of Ulster's technological prowess. Far from besmirching Belfast's image - the flawed product of a flawed society-Titanic now symbolizes what the "comeback city" could aspire to once again. Far from being the cockpit of crude sectarianism, where Catholics were unwelcome at best and persecuted at worst, Titanic now stands for peace, prosperity, progress, and political power sharing. No longer a Protestant ship for a Protestant people, Titanic has been stripped of its bigotry and repainted in catholic colors (catholic with a small "c," that is, open to all consumers and cultures regardless of religious denomination or political affiliation). The only barrier to entry is an ability to pay at the ticket booth:

The Signature Building has many parallels with Belfast itself. Just as Titanic was at the cutting edge of technology and innovation in the nineteen hundreds, the same is true today in the new Belfast, the renaissance city, which is at the fore- 
front of so many things-aerospace, wind turbines, robotic technology, culturally too. It's an inspirational message that's reflected in the Signature Building, which has the latest design technology and is at the leading edge of visitor experience. (Project manager, interview)

More than that, though, the Titanic has been recoded as Irish. In its day, when Britannia ruled the waves, Titanic was regarded as the epitome of Britishness, not only by the Ulstermen who built it but also in the rest of Ireland, where the sinking was seen as God's punishment for Protestant pride and Britain's perfidy. It remained so for decades thereafter. Despite the unfortunate fact that a large proportion of steerage passengers were Irish emigrants, no memorial to the country's Titanic victims was erected in Eire until 1998.

According to Hill (2004), this remarkable turnaround was triggered by Cameron's blockbuster movie, which portrayed the steamship in an ethereal Celtic light. Everything from the Enya-inspired soundtrack, through the wild Irish jigging below deck, to one character's claim that "fifteen thousand Irish hands built this ship," illustrates Cameron's Hibernian refit of the craft, as did his representation of the AngloSaxon first-class cadre as the bad guys. Painting Titanic green in this way would have caused a riot in the north of Ireland for most of the twentieth century. However, it had the miraculous effect of making the tainted ship acceptable to the Catholic community and indeed Ireland as a whole. Cameron's portrayal of Irishness may have been grotesquely stereotypical - an on-screen theme pub with added special effects-but it resonated with a war-weary society in the north and an emergent Celtic Tiger in the south. It thus set the scene and paved the way for today's money-spinning Titanic attractions.

The Titanic's loss, in effect, has been Belfast's gain (Barczewski 2004). And while the old tensions that the ship represents still remain, they'll be conveniently ignored while the cash registers are ringing and tourist dollars fill the former graving docks. This isn't so much a process of brand cocreation as a coconspiracy of consumer silence. Publicly, no one wants to rock the boat. Show me the money is the only show in town. Belfast's Signature Building has papered over the city's cultural contradictions with dark rides and computer graphics, the bread and circuses of the twentyfirst century. Titanic is a tragedy that can be commodified in a city where latter-day tragedies remain too raw to be turned into (officially sanctioned) visitor attractions.

On the surface, then, Titanic has evolved though a threestage process of countermemory making. It was neglected, then accepted, then idealized thereafter. Arguably it has come full circle, from silence to silence. However, the silence of shame amid the tumult of bigotry has been replaced by the silence of selfishness against a background of branding. Cash flows rather than ice floes top today's Titanic agenda. In Belfast at least, the myths, the meanings, the contradictions, the confusions, have metamorphosed into money-making marketing opportunities (Bryan 2012).

\section{TITANIC REFLECTIONS AND RESEARCH DIRECTIONS}

The above account of Titanic's rebranding parallels Thompson and Tian's (2008) myth-shaped study of the New South. In addition to the Celtic connection, the neoromantic archetype of hubris and nemesis is shared by both, as is the attempted creation of countermemories that are modern, meaningful, and money-minded. Our maritime myth-mash is more than a distant echo of Appalachia, though. Titanic mirrors many of the published articles on consumer mythology. All four of Kozinets's (2008) ideological technonarratives are evident in the Titanic complex, for instance. All four of Barbara Stern's (1995) archetypal mythoi are apparent, tragedy above all. When Muñiz and Schau (2005) attribute the Apple Newton's consumer appeal to its untimely demise, they could be writing about Titanic, which was cancelled in such a cruel and capricious fashion. The myth of the titan Prometheus, unearthed by Kozinets (2002) at Burning Man, is integral to Titanic's gigantic cultural complex, which has likewise evolved in line with Holt and Cameron's (2010) contention that iconic brands are established (and reestablished) at moments of societal rupture and ideological opportunity (Biel 2012; Howells 2012).

Titanic's myth-freighted cargo is second to none, and its ambiguity, when unpacked, reveals archetypal, remedial, spiritual, and geotemporal aspects. It is tempting, therefore, to infer that the legendary liner is a kind of master-myth, a mega-myth on a par with the deep metaphors and prototypes that underpin consumer discourse (Veryzer and Hutchinson 1998; Zaltman 2003). Attractive though it is, this idea of an über-myth is regressively reductive, a new twist on Joseph Campbell's (1968) monomyth or Lévi-Strauss's structuralism (1963) or the one-brand-one-myth mentality that prevails among management consultants (Atkin 2004; Hanlon 2006; Kuenstler 2012). Our research suggests that Titanic's explanatory ability - the insight it provides into particularly resonant brands-lies not in monolithic monumentalism but in multifariousness, in nebulousness, in confusing, contradictory, cumulative ambiguity. Just as the mystique of the contemporaneous Gibson Girl was attributable to her absence of specificity - she had something for everyone (Scott 2005)—so too Titanic's status as the archetypal disaster is due to its amorphousness.

RMS Titanic, to put it another way, is what movie director J. J. Abrams calls a "mystery box," a container of infinite possibilities that continues to fascinate because it remains unopened (Rose 2011). Akin to Bigfoot, Mothman, the $M a-$ rie Celeste, the Loch Ness monster, and the secret formulas that augment the allure of certain FMCGs, Titanic falls into the unsolved mystery category and is perpetuated thereby. Alongside Godzilla, Frankenstein, Dracula, and Jack the Ripper, Titanic is undead and undying.

Death, indeed, is a crucial issue here. Most extant studies of consumer mythology focus on life choices, how individuals mix and match and adapt and absorb the available repertoire of cultural myths to their own circumstances, their 
sense of self, their personal identity projects (Diamond et al. 2009; Holt 2002; Holt and Thompson 2004; Thompson 2004). Titanic, by contrast, forces consumers to think about mortality. It is thanatic as well as iconic. According to Turley (2005), paraphrasing Bauman (1992), death is the wellspring of all cultural activity and contemporary consumer behavior (Baudrillard 1993). In a secular society, consumers banish morbid thoughts of their inevitable demise-what Bonsu and Belk (2003) term "terror management"-with compensatory consumption (Mandel and Smeesters 2008; Rindfleisch, Burroughs, and Wong 2009). However, consumers of Titanic cannot avoid wondering what they would do in the same terrible circumstances. Would we face death bravely? Would we step aside for the weak and infirm? Would we leap like Bruce Ismay into the final lifeboat, leaving our dignity behind? Or would we, as many apparently did according to eyewitnesses, declare undying love to family and friends before facing the freezing waters? The same awful imponderables arise at Niagara Falls (Sternberg 1999), Waterloo battlefield (Seaton 1999), the Body Worlds exhibition (Goulding et al. 2013), and abandoned penal colonies like Norfolk Island (Best 2007). They are compounded by mass media representations, which daily replenish the "capital of fear" for consumers (Bauman 2007, 12) and attain their awful acme in media-magnified monstrosities like 9/11 (Sturken 2008) or, in an era when wireless was a wonder of the world, the Titanic atrocity:

Survivors even reported a reference to the Titanic in the midst of the chaotic attempts to evacuate the south tower of the World Trade Center. On the seventy-eighth floor, soon to be directly hit by the second plane, a man supposedly blocked two women who were trying to squeeze past him into an elevator and said, "This isn't the Titanic ladies. It's not women and children first." (Biel 2012, 233)

Titanic, Biel (2012) observes, is a metaphor for mortality. In the same way that death is often described as a journey (Fiedler 1967) - a journey where some remain suspended in ambiguous limbo (Pardo 1989)_Titanic's uncompleted voyage encapsulates both the imponderables of the afterlife and the uncertainties of those left behind (especially in the "if only" aftermath of premature deaths due to disease, disaster, or indeed drowning). As Ward $(2012$, vi) puts it in his poetic reflections on people's fascination with the sinking, "Having vanished below the horizon west of Ireland, the Titanic never reappeared. Instead, unseen in the witching hour of a moonless night, for the eternity between the collision and the final plunge, her passengers and crew found themselves poised between life and death."

A distillation of death, the unsinkable ship's extended afterlife in cultural memory is not unlike those of Elvis Presley, Marilyn Monroe, Jimi Hendrix, James Dean, Kurt Cobain, Amy Winehouse, and Wolfgang Amadeus Mozart (to say nothing of their fictional equivalents-Little Nell, Anna Karenina, Romeo, Juliet, Jay Gatsby, Jack Dawson, and so on). Titanic lived fast, died young, and attained secular immortality as a consequence (Hirschman 1990). It like- wise provides a rhetorical vehicle, similar to vampirism in contemporary teen culture (Butler 2013), that "gives us a way of talking about our fears without talking about our fears" (Haig 2013, 12). It triggers the imagination and tugs at the heartstrings of "thanatourists" (Seaton 1999), both those with a direct connection to Titanic and others who primarily experience it as entertainment. Myth, Barthes (1973, 144) cryptically remarks, "is a language which does not want to die: it wrests from the meanings which give it its sustenance an insidious, degraded survival, it provokes in them an artificial reprieve in which it settles comfortably, it turns them into speaking corpses."

At the same time, Titanic isn't all doom and gloom. Just as the sinking bestowed benefits on many participants, so too consumer research can take succor from the unsinkable brand. Ambiguity, as noted earlier, is generally regarded as something best avoided. The conventional brand management literature emphasizes the perils of opacity and the necessity for clarity (Bengtsson and Ostberg 2006). However, the consumer-captivating allure of ambiguity is increasingly being recognized by advertising researchers, even in situations where informants don't understand the ad (Dimofte and Yalch 2007). The inherent ambiguity of the fashion industry helps consumers cope with the opaque sartorial demands of today's smart-casual morass (Kaiser and Ketchum 2005). The ambiguity of online dating profiles attracts potential partners until interpersonal encounters ruin their romantic illusions (Norton, Frost, and Ariely 2007). Ambiguity is employed in upscale retail stores, where savvy sales associates shape the beliefs, behaviors, and brand choices of consumers as the transaction unfolds (Johnston and Sandberg 2008). Ambiguity is beneficial for transnational advertising agencies (Kates and Goh 2003) and adolescents engaging in acts of interpersonal one-upmanship (Ritson and Elliott 1999). Ambiguity is the essence of Hello Kitty's worldwide appeal, because the character's "cryptic simplicity," her blank facade, is infinitely interpretable (Walker 2008, 18). Ambiguity, furthermore, is a fertile frontier for Consumer Culture Theory in general and literary theory in particular. The latter has fallen into abeyance since the passing of its foremost exponent, Barbara B. Stern. As she observed in her inaugural article on literary criticism (Stern 1989), it leavens conventional approaches to consumer research and provides a rich resource for researchers going forward. Literary criticism facilitates better understanding of consumer myth-making and the multiple mythemes that meld in immemorial brands, occasions, experiences, and behaviors (Stern 1995).

It is insufficient, nevertheless, to note that ambiguity is ubiquitous or plays a part in consumer behavior, managerial decision making, and researchers' paradigmatic preferences. Ambiguity is not simply a variable, which is absent or present, strong or weak, high or low, as many quantitative consumer researchers presume. Ambiguity is variegated. There are several forms of ambiguity, three of which we have considered in relation to Titanic. Confusion, contradiction, and cumulation, we maintain, increase consumers' fascination with 
the myth-imbued liner. Although the resolution of ambiguity is enormously pleasurable, as studies of advertising rhetoric have shown (McQuarrie and Mick 1992, 1996, 1999), once the puzzle is solved its consumer appeal soon diminishes. When the puzzle can't be solved, or there is no definitive answer, consumer intrigue endures and myth comes into its own. The unfathomable imponderables of Titanic, Heyer (2012, xi) acknowledges, "has given her story a mythic status comparable to what we find with great works of literature, from the Bible to Shakespeare. At the time she was built Titanic was said to be 'unsinkable.' Had someone said this of her legacy, the truth of it would have been borne out a century later."

But what of the future? Titanic will doubtless steam on in cultural memory like a latter-day Atlantis (Pellegrino 1990), rising and falling with consumer sentiment and the zeitgeist. The implications for consumer research are more immediate. The benefits of ambiguity need to be more widely recognized than they are at present, since an element of antipathy still prevails (Aaker and Joachimsthaler 2009). Drawing researchers' attention to the advantages of ambiguity, as well as its continuing role in artistic and mythological expression (Rothenberg 2011) can only help in this regard. The seven types of ambiguity, as originally outlined by Empson (1930), are likewise ripe for future disambiguation and explanation. These explanations, moreover, are best pursued in a variety of domains and contexts. Iconic brands, by their very nature, are exceptions to the rule and the Titanic, as a thanatic icon, may be more atypical than most. The ambiguities that inhere in upmarket, downmarket, and midmarket brands, that are found across the spectrum of sectors from hi-tech to heritage, and that are evident in contrasting cultural, political, economic, and social circumstances, are worth exploring in detail, either in a myth-informed, Empson-enriched manner or by more conventional means.

Ambiguity, admittedly, isn't the be-all and end-all of branding, iconic or otherwise. To the contrary, it is evident that ambiguity draws some people on some occasions and deters them on others (Wilkinson 2006). Not all ambiguity is good ambiguity, because it can be used by unscrupulous marketers to bamboozle or mislead (Urbany 2013). Although Empson's taxonomy indicates that ambiguity is a multifaceted phenomenon, more research is needed on when and where it works and which aspects of ambiguity work better than others. Resonant, myth-wrapped brands are especially amenable to ambiguity, as Titanic amply demonstrates, but iconic brands are few in number. There is an ocean full of brands, some sinking, some swimming, which need to be rescued by consumer research. Whether the conventional "iceberg" model of branding is best suited to that task is another matter (de Chernatony 2010). Empsonian literary analysis, nevertheless, reveals that ambiguity helps explain why certain consumer myths resonate, helps unpack the appeal of iconic brands like Titanic, and helps fly the flag for cultural consumer research more generally.

\section{CONCLUSION}

In Ways of Seeing, his seminal study of Western art, John Berger (1972) notes that until the modern era, mythological paintings of gods, heroes, and legends of antiquity were very highly prized-far more so, in fact, than still-lifes, landscapes, or portraits. Nowadays, he continues, mythologically themed pictures strike us as vague and empty. But not because art lovers are less myth-minded than before. They appear vacuous because the paintings really are vague and empty. They were ambiguous by design, painted in a way that permitted viewers to project themselves into the scene - the depicted situation - and thereby take instruction on how to behave at heightened moments of life, such as heroic action, grand passion, courageous death.

Myths are ambiguous. They are "portals to both the unconscious and the transcendent" (Sherry and Schouten 2002, 230). They shape the lives of millions of people and comprise a key component of Consumer Culture Theory. This article considered the corpus of consumer myth-lit, focusing on its ambiguous underbelly. It extracted a typology of ambiguity from Empson's unruly literary theory, applied that typology to an iconic, myth-rich exemplar, indicated how ambiguous myths are meaningful for consumers, and recounted the remarkable story of an unsinkable brand, RMS Titanic.

\section{REFERENCES}

Aaker, David A., and Erich Joachimsthaler (2009), Brand Leadership, London: Pocket Books.

Armstrong, Karen (2005), A Short History of Myth, Edinburgh: Canongate.

$\rightarrow$ Arnould, Eric J., and Craig J. Thompson (2005), "Consumer Culture Theory (CCT): Twenty Years of Research," Journal of Consumer Research, 31 (March), 868-82.

$\rightarrow$ Arsel, Zeynep, and Craig J. Thompson (2011), "Demythologizing Consumption Practices: How Consumers Protect Their FieldDependent Identity Investments from Devaluing Marketplace Myths," Journal of Consumer Research, 37 (February), 791-806.

Atkin, Douglas (2004), The Culting of Brands: When Customers Become True Believers, New York: Portfolio.

$\rightarrow$ Bagchi, Rajesh, and Xingbo Li (2011), "Illusionary Progress in Loyalty Programs: Magnitudes, Reward-Distances, and StepSize Ambiguity," Journal of Consumer Research, 37 (February), 888-901.

Ballard, Robert (1995), The Discovery of the Titanic: Exploring the Greatest of All Lost Ships, London: Orion.

Bamossy, Gary J. (2005), "Star Gazing: the Mythology and Commodification of Vincent van Gogh," in Inside Consumption, ed. S. Ratneshwar and David Glen Mick, London: Routledge, 309-29.

Barczewski, Stephanie (2004), Titanic: A Night Remembered, London: Hambledon \& London.

Barthes, Roland (1973), Mythologies, trans. Annette Lavers, London: Paladin. (Originally published in 1957)

(1990), The Pleasure of the Text, trans. Richard Miller, Oxford: Blackwell. (Originally published in 1973)

$\rightarrow$ Bastos, Wilson, and Sidney J. Levy (2012), "A History of the 
Concept of Branding: Practice and Theory," Journal of Historical Research in Marketing, 4 (3), 347-68.

Bateman, Colin (2007), Titanic 2020, London: Hodder.

Baudrillard, Jean (1993), Symbolic Exchange and Death, trans. Iain Hamilton Grant, London: Sage. (Originally published in 1967)

(2002), Screened Out, trans. Chris Turner, London: Verso. (Originally published in 2000)

Bauman, Zygmunt (1992), Mortality, Immortality, and Other Life Strategies, Cambridge: Polity.

- (2007), Liquid Times: Living in an Age of Uncertainty, Cambridge: Polity.

Behe, George (1988), Titanic: Psychic Forewarnings of a Tragedy, Wellingborough: Patrick Stevens.

Belfast Telegraph (1999), "Council Sees Titanic Tourist Potential," Belfast, July 28.

Belk, Russell W., and Janeen A. Costa (1998), "The Mountain Man Myth: A Contemporary Consuming Fantasy," Journal of Consumer Research, 25 (December), 218-40.

Belk, Russell W., and Gulnur Tumbat (2003), "The Cult of Macintosh," in European Advances in Consumer Research, Vol. 6, ed. Stephen Brown and Darach Turley, Valdosta, GA: Association for Consumer Research, 1.

$\rightarrow$ Belk, Russell W., Melanie Wallendorf, and John F. Sherry Jr. (1989), "The Sacred and the Profane in Consumer Behavior: Theodicy on the Odyssey," Journal of Consumer Research, 16 (June), 1-39.

Bengtsson, Anders, and Jacob Ostberg (2006), "Researching the Cultures of Brands," in Handbook of Qualitative Research Methods in Marketing, ed. Russell W. Belk, Cheltenham, UK: Edward Elgar, 83-93.

Berger, John (1972), Ways of Seeing, London: Penguin.

Bergfelder, Tim, and Sarah Street, eds. (2004), "Introduction," in The Titanic in Myth and Memory: Representations in Visual and Literary Culture, London: I.B. Tauris, 1-11.

Best, Megan (2007), "Norfolk Island: Thanatourism, History and Visitor Emotions," Shima: The International Journal of Research into Island Cultures, 1 (2), 30-48.

Biel, Steven (2012), Down with the Old Canoe: A Cultural History of the Titanic Disaster, 2nd ed., New York: Norton.

Björkfors, Peter (2004), "The Titanic Disaster and Images of National Identity in Scandinavian Literature," in The Titanic in Myth and Memory: Representations in Visual and Literary Culture, ed. Tim Bergfelder and Sarah Street, London: I.B. Tauris, 53-62.

$\rightarrow$ Bonsu, Samuel K., and Russell W. Belk (2003), "Do Not Go Cheaply into That Good Night: Death-Ritual Consumption in Asante, Ghana," Journal of Consumer Research, 30 (June), $41-55$.

Brooks, Cleanth (1968), The Well Wrought Urn: Studies in the Structure of Poetry, London: Metheun.

Bryan, Dominic (2012), "Titanic Town: Living in a Landscape of Conflict," in Belfast 400: People, Place and History, ed. Sean J. Connolly, Liverpool: Liverpool University Press, 317-53.

Butler, Erik (2013), The Rise of the Vampire, London: Reaktion.

Butler, Robert Olen, ed. (1997), "Titanic Victim Speaks through Waterbed," in Tabloid Dreams: Stories, London: Minerva, $1-20$.

Cameron, James (2003), Ghosts of the Abyss, DVD, Walt Disney Pictures, 58 minutes.

Cameron, Stephen (2011), Titanic: Belfast's Own, Newtownards, Ireland: Colourpoint.
Campbell, Joseph (1968), The Hero with a Thousand Faces, 2nd ed., Princeton, NJ: Princeton University Press.

$\rightarrow$ Cayla, Julien, and Giana M. Eckhardt (2008), "Asian Brands and the Shaping of a Transnational Imagined Community," Journal of Consumer Research, 35 (August), 216-30.

$\rightarrow$ Cohen, Percy (1969), "Theories of Myth," Man 4 (4), 337-53.

Costello, Mary (1992), Titanic Town: Memoirs of a Belfast Girlhood, London: Metheun.

Cova, Bernard, Robert V. Kozinets, and Avi Shankar, eds. (2007), Consumer Tribes, London: Sage.

Cross, Samantha, N. N., and Mary Gilly (2012), "Research Methods for Innovative Cultural Marketing Management (CMM): Strategy and Practices," in Marketing Management: A Cultural Perspective, ed. Lisa Peñaloza, Nil Toulouse, and Luca M. Visconti, London: Routledge, 261-78.

Daily Mail (2012), “'Just Found Out Titanic Really Happened!' The Tweeters Who Thought World's Most Famous Shipwreck Was Just a Film,” http://www.dailymail.co.uk/news/article2129971.

Davenport-Hines, Richard (2012), Titanic Lives: Migrants and Millionaires, Conmen and Crew, London: Harper.

Davis, Garrick, ed. (2008), "The Golden Age of Poetry Criticism," in Praising It New: The Best of the New Criticism, Athens, $\mathrm{OH}$ : Swallow Press, xxi-xxviii.

Dawkins, R. (1998), Unweaving the Rainbow: Science, Delusion and the Appetite for Wonder, London: Allen Lane.

de Chernatony, Leslie (2010), From Brand Vision to Brand Evaluation, Oxford: Butterworth-Heinemann.

$\rightarrow$ Diamond, Nina, John F. Sherry Jr., Albert M. Muñiz Jr., Mary Ann McGrath, Robert V. Kozinets, and Stefania Borghini (2009), "American Girl and the Brand Gestalt: Closing the Loop on Sociocultural Branding Research," Journal of Marketing, 73 (May), 118-34.

$\rightarrow$ Dimofte, Claudiu V., and Richard F. Yalch (2007), "Consumer Response to Ambiguous Brand Slogans," Journal of Consumer Research, 33 (March), 515-22.

Donnelly, K. J. (2004), "Riverdancing as the Ship Goes Down," in The Titanic in Myth and Memory, ed. Tim Bergfelder and Sarah Street, London: I.B. Tauris, 205-14.

Eagleton, Terry (1983), Literary Theory: An Introduction, Oxford: Blackwell.

Eaton, John P., and Charles A. Haas (2011), Titanic: Destination Disaster, Yeovil: Haynes.

Ebeling, Mary (2010), "Marketing Chimeras: The Biovalue of Branded Medical Devices," in Blowing Up the Brand: Critical Perspectives on Consumer Culture, ed. Melissa Aronczyk and Devon Powers, New York: Peter Lang, 241-59.

Economist (2012), "Horrible Histories," Belfast, March 31, 37.

Eliot, Thomas S. (1922), The Waste Land, London: Faber.

Empson, William (1930), Seven Types of Ambiguity, London: Chatto \& Windus.

Eyers, Jonathan (2013), Final Voyage: The World's Worst Maritime Disasters, London: Bloomsbury.

Fanning, John (1999), "Tell Me a Story: The Future of Branding," Irish Marketing Review, 12 (2), 3-15.

Fiedler, Leslie A. (1967), Love and Death in the American Novel, London: Cape.

Forbeck, Matt (2012), Carpathia, Nottingham, UK: Angry Robot.

Foster, John Wilson (1997), The Titanic Complex: A Cultural Manifest, Vancouver: Belcouver Press. - (2002), The Age of Titanic: Cross-Currents of AngloAmerican Culture, Dublin: Merlin. 
$\rightarrow$ Fournier, Susan, and Jill Avery (2011), "The Uninvited Brand," Business Horizons, 54 (3), 193-207.

Geertz, Clifford, ed. (1973), "Thick Description: Toward an Interpretive Theory of Culture," in The Interpretation of Cultures, London: Fontana, 3-30.

Gershoff, Andrew D., Ashesh Mukherjee, and Anirban Mukhopadhyay (2007), "Few Ways to Love but Many Ways to Hate: Attribute Ambiguity and the Positivity Effect in Agent Evaluation," Journal of Consumer Research, 33 (March), 499505.

$\rightarrow$ Giesler, Markus (2008), "Conflict and Compromise: Drama in Marketplace Evolution," Journal of Consumer Research, 34 (April), 739-53.

$\rightarrow$ —_ (2012), "How Doppelgänger Brand Images Influence the Market Creation Process: Longitudinal Insights from the Rise of Botox Cosmetic," Journal of Marketing, 76 (November), $55-68$.

Goldman, Robert, and Stephen Papson (1996), Sign Wars: The Cluttered Landscape of Advertising, New York: Guilford.

$\rightarrow$ Goulding, Christina, Michael Saren, and Andrew Lindridge (2013), "Reading the Body at von Hagen's 'Body Worlds," Annals of Tourism Research, 40 (January), 306-30.

Graff, Gerald (1995), "Determinacy/Indeterminacy," in Critical Terms for Literary Study, ed. Frank Lentricchia and Thomas McLaughlin, Chicago: University of Chicago Press, 163-76.

Gray, John (2013), The Silence of Animals: On Progress and Other Modern Myths, London: Allen Lane.

$\rightarrow$ Ha, Young-Won, and Stephen J. Hoch (1989), "Ambiguity, Processing Strategy, and Advertising-Evidence Interactions," Journal of Consumer Research, 16 (December), 354-60.

Hackley, Christopher (2003), Doing Research Projects in Marketing, Management and Consumer Research, London: Routledge.

Haffenden, John (2005), William Empson: Among the Mandarins, Oxford: Oxford University Press.

Haig, Matt (2013), "We're Suckers for the Undead," The Times, April 27, 12.

Hammond, Michael (2004), "My Poor Brave Men-Time, Space, and Gender in Southampton's Memory of the Titanic," in The Titanic in Myth and Memory, ed. Tim Bergfelder and Sarah Street, London: I.B. Tauris, 25-36.

Hanlon, Patrick (2006), Primal Branding: Create Zealots for Your Brand, Your Company, and Your Future, New York: Free Press.

Heding, Tilde, Charlotte F. Knudtzen, and Mogens Bjerre (2009), Brand Management: Research, Theory and Practice, London: Routledge.

Heyer, Paul (1995), Titanic Legacy: Disaster as Media Event and Myth, Westport, CT: Praeger

___ (2012), Titanic Century: Media, Myth, and the Making of a Cultural Icon, Westport, CT: Praeger.

Hill, John (2004), "The Relaunching of Ulster Pride: The Titanic, Belfast and Film," in The Titanic in Myth and Memory, ed. Tim Bergfelder and Sarah Street, London: I.B. Tauris, 15-24.

$\rightarrow$ Hirschman, Elizabeth C. (1988), "The Ideology of Consumption: A Structural-Syntactical Analysis of Dallas and Dynasty," Journal of Consumer Research, 15 (December), 344-59.

- (1990), "Secular Immortality and the American Ideology of Affluence," Journal of Consumer Research, 17 (June), $31-42$.

$\rightarrow$ Hoch, Stephen J., and John Deighton (1989), "Managing What Consumers Learn from Experience," Journal of Marketing, 53 (April), 1-20.
Holbrook, Morris B. (1988) "The Psychoanalytical Interpretation of Consumer Research: I Am an Animal," in Research in Consumer Behavior, Vol. 3, ed. Elizabeth C. Hirschman and Jagdish N. Sheth, Greenwich, CT: JAI Press, 149-78.

$\rightarrow$ Holt, Douglas B. (1995), "How Consumers Consume: A Typology of Consumption Practices," Journal of Consumer Research, 22 (June), 1-16.

$\rightarrow$ _ _ (2002), "Why Do Brands Cause Trouble? A Dialectical Theory of Consumer Culture and Branding," Journal of Consumer Research, 29 (June), 70-90.

(2003), "Brands and Branding," HBS Cultural Strategy Group, Working Paper 503-045, Harvard Business School, Boston.

- (2004), How Brands Become Icons: The Principles of Cultural Branding, Cambridge, MA: Harvard Business School Press.

(2005), "How Societies Desire Brands: Using Cultural Theory to Explain Brand Symbolism," in Inside Consumption, ed. S. Ratneshwar and David Glen Mick, London: Routledge, 273-91.

Holt, Douglas B., and Douglas Cameron (2010), Cultural Strategy: Using Innovative Ideologies to Build Breakthrough Brands, Oxford: Oxford University Press.

$\rightarrow$ Holt, Douglas B., and Craig J. Thompson (2004), "Man-of-Action Heroes: The Pursuit of Heroic Masculinity in Everyday Consumption," Journal of Consumer Research, 31 (September), 425-40.

Hooper, John, and Tracy McVeigh (2012), "Have You Seen Titanic? That's Exactly What It Was Like for Us," The Observer, January $15,2-3$.

Howells, Richard (2012), The Myth of the Titanic, centenary edition, Basingstoke: Palgrave.

Hunt, Shelby D. (2002), Foundations of Marketing Theory: Toward a General Theory of Marketing, Armonk, NY: M. E. Sharpe.

Johnson, Christopher (2011), Microstyle: The Art of Writing Little, New York: Norton.

$\rightarrow$ Johnston, Allanah, and Jörgen Sandberg (2008), "Controlling Service Work: An Ambiguous Accomplishment between Employees, Management, and Customers," Journal of Consumer Culture, 8 (3), 389-417.

Johnston, Kevin (2008), In the Shadow of Giants: A Social History of the Belfast Shipyards, Dublin: Gill \& Macmillan.

Kahn, Barbara E., and Robert J. Meyer (1991), "Consumer Multiattribute Judgments under Attribute-Weight Uncertainty," Journal of Consumer Research, 17 (March), 508-22.

$\rightarrow$ Kahn, Barbara E., and Rakesh K. Sarin (1988), "Modeling Ambiguity in Decisions under Uncertainty," Journal of Consumer Research, 15 (September), 265-72.

Kaiser, Susan B., and Karyl Ketchum (2005), "Consuming Fashion as Flexibility: Metaphor, Cultural Mood, and Materiality," in Inside Consumption, ed. S. Ratneshwar and David Glen Mick, London: Routledge, 122-43.

$\rightarrow$ Kates, Steven M., and Charlene Goh (2003), "Brand Morphing: Implications for Advertising Theory and Practice," Journal of Advertising, 32 (1), 59-68.

Keller, Alexandra (1999), "Size Does Matter: Notes on Titanic and James Cameron as Blockbuster Auteur," in Titanic: Anatomy of a Blockbuster, ed. Kevin S. Sandler and Gaylyn Studlar, New Brunswick, NJ: Rutgers University Press, 132-54.

Keller, Kevin Lane (1999), "Brand Mantras: Rationale, Criteria, and Examples," Journal of Marketing Management, 15 (1), 43-51. 
Kincade, Rebecca (2011), "Unsinkable Adventure," Business Month, 12 (September), 18-20.

King, Alasdair (2004), "Enzensberger's Titanic: The Sinking of the German Left and the Aesthetics of Survival," in The Titanic in Myth and Memory: Representations in Visual and Literary Culture, ed. Tim Bergfelder and Sarah Street, London: I.B. Tauris, 73-84.

$\rightarrow$ Kleine, Robert E., and Jerome B. Kernan (1991), "Contextual Influences on the Meanings Ascribed to Ordinary Consumption Objects," Journal of Consumer Research, 18 (December), 311-24.

$\rightarrow$ Kozinets, Robert V. (2001), "Utopian Enterprise: Articulating the Meaning of Star Trek's Culture of Consumption," Journal of Consumer Research, 28 (June), 67-89.

$\rightarrow$ _ _ (2002), "Can Consumers Escape the Market? Emancipatory Illuminations from Burning Man," Journal of Consumer Research, 29 (June), 20-38.

$\rightarrow$ __ (2008), "Technology/Ideology: How Ideological Fields Influence Consumers' Technology Narratives," Journal of Consumer Research, 34 (April), 865-81.

(2010), Netnography: Doing Ethnographic Research Online, Thousand Oaks, CA: Sage.

$\rightarrow$ Kozinets, Robert V., and Jay M. Handelman (2004), "Adversaries of Consumption: Consumer Movements, Activism, and Ideology," Journal of Consumer Research, 31 (December), 691-704.

$\rightarrow$ Kristensen, Dorthe B., Heidi Boye, and Søren Askegaard (2011), "Leaving the Milky Way! The Formation of a Consumer Counter Mythology," Journal of Consumer Culture, 11 (2), 195-214.

Kuenstler, Walt (2012), Myth, Magic and Marketing: An Irreverent History of Branding from the Acropolis to the Apple Store, Havertown, PA: Zolexa.

$\rightarrow$ Lee, Michelle P., and Kwanho Suk (2010), "Disambiguating the Role of Ambiguity in Perceptual Assimilation and Contrast Effects," Journal of Consumer Research, 36 (February), 890-97.

Lennon, John, and Malcolm Foley (2000), Dark Tourism: The Attraction of Death and Disaster, London: Continuum.

Lentricchia, Frank (1980), After the New Criticism, Chicago: University of Chicago Press.

Lévi-Strauss, Claude (1963), Structural Anthropology, trans. Claire Jacobson and Brooke G. Schoeff, New York: Basic Books. (Originally published in 1958)

$\rightarrow$ Levy, Sidney J. (1981), "Interpreting Consumer Mythology: A Structural Approach to Consumer Behavior," Journal of Marketing, 45 (Summer), 49-61.

Lightoller, Charles (1935), Titanic and Other Ships, London: Nicholson \& Watson.

Lord, Walter (1955), A Night to Remember, New York: R. W. Holt. - (1986), The Night Lives On: Thoughts, Theories and Revelations about the Titanic, London: Penguin.

(1995), "Introduction," in The Discovery of the Titanic, Robert D. Ballard, London: Orion, 6-8.

Lubin, David M. (1999), Titanic, London: British Film Institute.

$\rightarrow$ Luedicke, Marius K., Craig J. Thompson, and Markus Giesler (2010), "Consumer Identity Work as Moral Protagonism: How Myth and Ideology Animate a Brand-Mediated Moral Conflict," Journal of Consumer Research, 36 (April), 1016-32.

MacQuitty, William (2000), Titanic Memories: The Making of "A Night to Remember," London: National Maritime Museum.

Maltin, Tim, and Eloise Aston (2010), 101 Things You Thought
You Knew about the Titanic . . . but Didn't! London: Beautiful Books.

$\rightarrow$ Mandel, Naomi, and Dirk Smeesters (2008), "The Sweet Escape: Effects of Mortality Salience on Consumption Quantities for High- and Low-Self-Esteem Consumers," Journal of Consumer Research, 35 (August), 309-23.

Matthews, Rupert (2011), Titanic: The Tragic Story of the Ill-fated Ocean Liner, London: Arcturus.

$\rightarrow$ McAlexander, James H., John W. Schouten, and Harold F. Koenig (2002), "Building Brand Community," Journal of Marketing, 66 (January), 38-54.

McCaughan, Michael (1998), "Titanic: Out of the Depths and into the Culture," in Symbols in Northern Ireland, ed. Anthony D. Buckley, Belfast: Institute of Irish Studies, 133-51.

McCracken, Grant (2005), "Meaning-Management: An Anthropological Approach to the Creation of Value," in Culture and Consumption II: Markets, Meaning, and Brand Management, Bloomington: Indiana University Press, 175-91.

__ (2012), Culturematic, Boston: Harvard Business Review Press.

McKeown, Lesley-Anne (2012), "Swamped by an Ocean of Titanic Merchandise," Belfast Telegraph, February 16, 3.

$\rightarrow$ McQuarrie, Edward F., and David Glen Mick (1992), "On Resonance: A Critical Pluralistic Inquiry into Advertising Rhetoric," Journal of Consumer Research, 19 (September), 180-97.

$\rightarrow$ —_ (1996), "Figures of Rhetoric in Advertising Language," Journal of Consumer Research, 22 (March), 424-37.

$\rightarrow$ _ _ (1999), "Visual Rhetoric in Advertising: Text-Interpretive, Experimental, and Reader-Response Analyses," Journal of Consumer Research, 37-54.

$\rightarrow$ Meyers-Levy, Joan, and Prashant Malaviya (1999), "Consumers' Processing of Persuasive Advertisements: An Integrative Framework of Persuasion Theories," Journal of Marketing, 63 (Special Issue), 45-60.

$\rightarrow$ Mick, David Glen, and Claus Buhl (1992), "A Meaning-Based Model of Advertising Experiences," Journal of Consumer Research, 19 (December), 317-38.

$\rightarrow$ Mick, David Glen, and Susan Fournier (1998), "Paradoxes of Technology: Consumer Cognizance, Emotion, and Coping Strategies," Journal of Consumer Research, 25 (September), 123-43.

Mitchell, David (2004), Cloud Atlas, London: Sceptre.

Molony, Senan (2012), The Irish aboard Titanic, Cork: Mercier.

$\rightarrow$ Muñiz, Albert M., Jr., and Hope Jensen Schau (2005), "Religiosity in the Abandoned Apple Newton Brand Community," Journal of Consumer Research, 31 (March), 737-47.

$\rightarrow$ Muthukrishnan, A. V. (1995), "Decision Ambiguity and Incumbent Brand Advantage," Journal of Consumer Research 22 (June), 98-109.

Nash, Melanie, and Martti Lahti (1999), "Almost Ashamed to Say I Am One of Those Girls: Titanic, Leonardo DiCaprio, and the Paradoxes of Girls' Fandom," in Titanic: Anatomy of a Blockbuster, ed. Kevin S. Sandler and Gaylyn Studlar, New Brunswick, NJ: Rutgers University Press, 64-88.

$\rightarrow$ Neill, William J. V. (2001), "Marketing the Urban Experience: Reflections on the Place of Fear in the Promotional Strategies of Belfast, Detroit and Berlin," Urban Studies, 38 (5-6), 815-28.

$\rightarrow$ _ search for Representation of 'Post-conflict' Belfast," Space and Polity, 10 (2), 109-20.

___ (2010), "Belfast. Rebranding the Renaissance City: From 
the Troubles to Titanic Quarter," in Urban Design and the British Urban Renaissance, ed. John Punter, London: Routledge, 305-21.

Neville, Stuart (2010), The Twelve, London: Vintage.

$\rightarrow$ Norton, Michael I., Jeana H. Frost, and Don Ariely (2007), "Less Is More: The Lure of Ambiguity, or Why Familiarity Breeds Contempt," Journal of Personality and Social Psychology, 92 (1), 97-105.

$\rightarrow$ Pardo, Italo (1989), "Life, Death and Ambiguity in the Social Dynamics of Inner Naples," Man, New Series, 24 (1), 103 23.

Patten, Louise (2010), Good as Gold, London: Quercus.

Pearson, Timothy R. (2011), The Old Rules of Marketing Are Dead: Six New Rules to Reinvent Your Brand and Reignite Your Business, New York: McGraw Hill.

Pellegrino, Charles (1990), Her Name Titanic: The Untold Story of the Sinking and Finding of the Unsinkable Ship, New York: Avon.

—__ (2012), Farewell Titanic: Her Final Legacy, New York: John Wiley.

$\rightarrow$ Peñaloza, Lisa (2001), "Consuming the American West: Cultural Meaning and Memory at a Stock Show and Rodeo," Journal of Consumer Research, 28 (December), 369-98.

Pendergrast, Mark (1993), For God, Country and Coca-Cola: The Unauthorized History of the World's Most Popular Soft Drink, London: Weidenfeld \& Nicolson.

$\rightarrow$ Peracchio, Laura A., and Joan Meyers-Levy (1994), "How Ambiguous Cropped Objects in Ad Photos Can Affect Product Evaluations," Journal of Consumer Research, 21 (June), 190-204.

$\rightarrow$ Puntoni, Stefano, Jonathan E. Schroeder, and Mark Ritson (2010) "Meaning Matters: Polysemy in Advertising," Journal of Advertising, 39 (2), 51-64.

Ravin, Yael, and Claudia Leacock, eds. (2000), "Polysemy: An Overview," in Polysemy: Theoretical and Computational Approaches, Oxford: Oxford University Press, 1-29.

Reeves, Rosser (1961), Reality in Advertising, London: MacGibbon \& Kee.

Richards, I. A. (1929), Practical Criticism: A Study of Literary Judgment, London: Routledge.

Ries, Al, and Jack Trout (2001), Positioning: The Battle for Your Mind, rev. ed., New York: McGraw-Hill.

$\rightarrow$ Rindfleisch, Aric, James E. Burroughs, and Nancy Wong (2009), "The Safety of Objects: Materialism, Existential Insecurity, and Brand Connection," Journal of Consumer Research, 36 (June), 1-16.

$\rightarrow$ Ritson, Mark, and Richard Elliott (1999), "The Social Uses of Advertising: An Ethnographic Study of Adolescent Advertising Audiences," Journal of Consumer Research, 26 (December), 260-77.

Rose, Frank (2011), The Art of Immersion: How the Digital Generation Is Remaking Hollywood, Madison Avenue, and the Way We Tell Stories, New York: Norton.

Rothenberg, David (2011), Survival of the Beautiful: Art, Science and Evolution, London: Bloomsbury.

Ruthven, K. K. (1976), Myth, London: Metheun.

Salmon, Christian (2010), Storytelling: Bewitching the Modern Mind, trans. David Macey, London: Verso. (Originally published in 2007)

$\rightarrow$ Schouten, John, and James H. McAlexander (1995), "Subcultures of Consumption: An Ethnography of the New Bikers," Journal of Consumer Research, 22 (June), 43-61.

Schroeder, Jonathan E., and Miriam Salzer-Mörling, eds. (2006),
"Introduction: The Cultural Codes of Branding," in Brand Culture, London: Routledge, 1-12.

Scott, Linda M. (2005), Fresh Lipstick: Redressing Fashion and Feminism, New York: Palgrave Macmillan.

Scott, Linda M., and Pauline Maclaran (2013), "Consuming the Mists and Myths of Avalon: A Case Study of Pilgrimage in Glastonbury," in Consumption and Spirituality, ed. Diego Rinallo, Linda Scott, and Pauline Maclaran, London: Routledge, 195-208.

$\rightarrow$ Seaton, Anthony V. (1999), "War and Thanatourism," Annals of Tourism Research, 26 (1), 130-58.

Segal, Robert A. (2004), Myth: A Very Short Introduction, Oxford: Oxford University Press.

Seil, William (1996), Sherlock Holmes and the Titanic Tragedy: A Case to Remember, London: Breese Books.

Shankar, Avi, Richard Elliott, and Christina Goulding (2001), "Understanding Consumption: Contributions from a Narrative Perspective," Journal of Marketing Management, 17 (3/4), 429-53.

Sheridan, Michael (2013), "Romantics Offer \$1m for Each Cabin on Titanic II," Sunday Times, February 24, 30.

$\rightarrow$ Sherry, John F., Jr., and John Schouten (2002), "A Role for Poetry in Consumer Research," Journal of Consumer Research, 29 (September), 218-34.

Sides, Hampton (2012), "Unseen Titanic," National Geographic, 221 (4), 78-99.

Sivulka, Juliann (2011), Soap, Sex, and Cigarettes: A Cultural History of American Advertising, 2nd ed., Boston: Wadsworth.

Steel, Danielle (1991), No Greater Love, London: Bantam.

$\rightarrow$ Stern, Barbara B. (1989), "Literary Criticism and Consumer Research: Overview and Illustrative Analysis," Journal of Consumer Research, 16 (December), 322-34.

$\rightarrow$ _ (1995), "Consumer Myths: Frye's Taxonomy and the Structural Analysis of Consumption Text," Journal of Consumer Research 22 (September), 164-85.

$\rightarrow$ _ _ (2006), "What Does Brand Mean? Historical-Analysis Method and Construct Definition," Journal of the Academy of Marketing Science, 35 (2), 216-33.

Sternberg, Ernest (1999), The Economy of Icons: How Business Manufactures Meaning, Westport, CT: Praeger.

$\rightarrow$ Stone, Philip R., and Richard Sharpley (2008), "Consuming Dark Tourism: A Thanatological Perspective," Annals of Tourism Research, 35 (2), 574-95.

Studlar, Gaylyn, and Kevin S. Sandler (1999), "Introduction: The Seductive Waters of James Cameron's Film Phenomenon," in Titanic: Anatomy of a Blockbuster, ed. Kevin S. Sandler and Gaylyn Studlar, New Brunswick, NJ: Rutgers University Press, 1-13.

Sturken, Marita (2008), Tourists of History: Memory, Kitsch, and Consumerism from Oklahoma City to Ground Zero, Raleigh, NC: Duke University Press.

$\rightarrow$ Thompson, Craig J. (2004), "Marketplace Mythology and Discourses of Power," Journal of Consumer Research, 31 (June), $162-80$.

$\rightarrow$ Thompson, Craig J., Eric Arnould, and Markus Giesler (2013), "Discursivity, Difference, and Disruption: Genealogical Reflections on the Consumer Culture Theory Heteroglossia," Marketing Theory, 13 (2), 149-74.

$\rightarrow$ Thompson, Craig J., and Zeynep Arsel (2004), "The Starbucks Brandscape and Consumers' (Anticorporate) Experiences of Glocalization," Journal of Consumer Research, 31 (December), 631-42. 
Thompson, Craig J., and Diana L. Haytko (1997), "Speaking of Fashion: Consumers' Uses of Fashion Discourses and the Appropriation of Countervailing Cultural Meanings," Journal of Consumer Research, 24 (June), 15-42.

Thompson, Craig J., Aric Rindfleisch, and Zeynep Arsel (2006), "Emotional Branding and the Strategic Value of the Doppelgänger Brand Image," Journal of Marketing, 70 (1), 50-64.

Thompson, Craig J., and Siok Kuan Tambyah (1999), "Trying to Be Cosmopolitan," Journal of Consumer Research, 26 (December), 214-41.

$\rightarrow$ Thompson, Craig J., and Kelly Tian (2008), "Reconstructing the South: How Commercial Myths Compete for Identity Value through the Ideological Shaping of Popular Memories and Countermemories," Journal of Consumer Research, 34 (February), 595-613.

The-Titanic.com (2011), "Top Ten Titanic Legends and Myths," video, dir. TitanicStories, http://www.youtube.com/watch?v= J_Mtb3Fw4EM.

TitanicBerg (2007), "Titanic Myths and Rumors," http://www .titanicberg.com/Titanic_Myths_and_Rumors.html.

Titanic-Titanic (2000), "Titanic Myths, Legends, Truths, and Facts," http://www.titanic-titanic.com/titanic_myths.shtml.

Turley, Darach (2005), "Death, Where Is Thy Sting? Mortality and Consumer Motivation in the Writings of Zygmunt Bauman," in Inside Consumption, ed. S. Ratneshwar and David Glen Mick, London: Routledge, 67-85.

$\rightarrow$ Twitchell, James B. (2004), "An English Teacher Looks at Branding," Journal of Consumer Research, 31 (2), 484-89.

Urbany, Joel E. (2013), "The Case for Clarity," in Marketing and the Common Good: Essays from Notre Dame on Societal Impact, ed. Patrick E. Murphy and John F. Sherry Jr., New York: Routledge, forthcoming. $\rightarrow$ Üstüner, Tuba, and Douglas B. Holt (2010), "Toward a Theory of Status Consumption in Less Industrialized Countries," Journal of Consumer Research, 37 (June), 37-56.

$\rightarrow$ Üstüner, Tuba, and Craig J. Thompson (2012), "How Marketplace Performances Produce Interdependent Status Games and Contested Forms of Symbolic Capital," Journal of Consumer Research, 38 (February), 796-814.

$\rightarrow$ Veryzer, Robert W., Jr., and J. Wesley Hutchinson (1998), "The Influence of Unity and Prototypicality on Aesthetic Responses to New Product Designs," Journal of Consumer Research, 24 (March), 374-94.

Wade, Wyn Craig (1986), The Titanic: End of a Dream, London: Penguin.

Walker, Rob (2008), I'm with the Brand: The Secret Dialogue between What We Buy and Who We Are, London: Constable.

Ward, Greg (2012), The Rough Guide to the Titanic: The Legend, the Controversies, the Awful Truth, London: Rough Guides.

White, John D. T. (2011), The RMS Titanic Miscellany, Dublin: Irish Academic Press.

Wilkinson, David J. (2006), The Ambiguity Advantage: What Great Leaders Are Great At, Basingstoke: Palgrave Macmillan.

Wilkinson, Michael, and Robert Hamilton (2011), The Story of the Unsinkable Titanic, Croxley Green, UK: Transatlantic Press.

Zaltman, Gerald (2003), How Customers Think: Essential Insights into the Mind of the Market, Boston: Harvard Business School Press.

$\rightarrow$ Zhao, Xin, and Russell W. Belk (2008), "Politicizing Consumer Culture: Advertising's Appropriation of Political Ideology in China's Social Transition," Journal of Consumer Research, 35 (August), 231-44.

Žižek, Slavoj (2009), "The Ambiguity of Obscenity," YouTube video, www.egs.edu. 